\title{
Water-soluble organic aerosol in the Los Angeles Basin and outflow regions: Airborne and ground measurements during the 2010 CalNex field campaign
}

\author{
Hanh T. Duong, ${ }^{1}$ Armin Sorooshian, ${ }^{1,2}$ Jill S. Craven, ${ }^{3}$ Scott P. Hersey, ${ }^{3}$ \\ Andrew R. Metcalf, ${ }^{3}$ Xiaolu Zhang, ${ }^{4}$ Rodney J. Weber, ${ }^{4}$ Haflidi Jonsson, ${ }^{5}$ \\ Richard C. Flagan, ${ }^{3}$ and John H. Seinfeld ${ }^{3}$
}

Received 3 August 2011; revised 21 September 2011; accepted 25 September 2011; published 18 November 2011.

[1] A particle-into-liquid sampler coupled to a total organic carbon analyzer (PILS-TOC) quantified particulate water-soluble organic carbon (WSOC) mass concentrations during the May 2010 deployment of the Center for Interdisciplinary Remotely Piloted Aircraft Studies (CIRPAS) Twin Otter in the CalNex field study. WSOC data collected during 16 flights provide the first spatiotemporal maps of WSOC in the San Joaquin Valley, Los Angeles Basin, and outflow regions of the Basin. WSOC was consistently higher in concentration within the Los Angeles Basin, where sea breeze transport and Basin topography strongly influence the spatial distribution of WSOC. The highest WSOC levels were associated with fire plumes, highlighting the importance of both primary and secondary sources for WSOC in the region. Residual pollution layers enriched with WSOC are observed aloft up to an altitude of $3.2 \mathrm{~km}$ and the highest WSOC levels for each flight were typically observed above $500 \mathrm{~m}$. Simultaneous ground WSOC measurements during aircraft overpasses in Pasadena and Riverside typically exhibit lower levels, especially when relative humidity $(\mathrm{RH})$ was higher aloft suggestive of the influence of aerosol-phase water. This points to the underestimation of the radiative effects of WSOC when using only surface measurements. Reduced aerosol-phase water in the eastern desert outflow region likely promotes the re-partitioning of WSOC to the gas phase and suppression of processes to produce these species (partitioning, multiphase chemistry, photolytic production); as a result, WSOC is reduced relative to sulfate (but not as much as nitrate) as aerosol is advected from the Basin to the outflows.

Citation: Duong, H. T., A. Sorooshian, J. S. Craven, S. P. Hersey, A. R. Metcalf, X. Zhang, R. J. Weber, H. Jonsson, R. C. Flagan, and J. H. Seinfeld (2011), Water-soluble organic aerosol in the Los Angeles Basin and outflow regions: Airborne and ground measurements during the 2010 CalNex field campaign, J. Geophys. Res., 116, D00V04, doi:10.1029/2011JD016674.

\section{Introduction}

[2] The spatiotemporal distribution of aerosol chemical composition is influential in aerosol interactions with water vapor and radiation. Organics are of major importance in this regard as they typically represent between 20 and $90 \%$ of fine aerosol mass [Kanakidou et al., 2005]. As it is vir-

\footnotetext{
${ }^{1}$ Department of Chemical and Environmental Engineering, University of Arizona, Tucson, Arizona, USA.

${ }^{2}$ Department of Atmospheric Sciences, University of Arizona, Tucson, Arizona, USA.

${ }^{3}$ Departments of Environmental Science and Engineering and Chemical Engineering, California Institute of Technology, Pasadena, California, USA

${ }^{4}$ School of Earth and Atmospheric Sciences, Georgia Institute of Technology, Atlanta, Georgia, USA.

${ }^{5}$ Center for Interdisciplinary Remotely-Piloted Aircraft Studies, Naval Postgraduate School, Monterey, California, USA.

Copyright 2011 by the American Geophysical Union. 0148-0227/11/2011JD016674
}

tually impossible to speciate and quantify the entire spectrum of particulate organic compounds, it is useful to examine classes of organic species. A key category of particulate organics is water-soluble organic species, where watersoluble organic carbon (WSOC) has been shown to account for between 40 and $85 \%$ of the global organic carbon (OC) budget [Ruellan et al., 1999; Graham et al., 2002; MayolBracero et al., 2002; Jaffrezo et al., 2005; Decesari et al., 2006]. In the absence of biomass burning, WSOC is often considered a proxy for secondary organic aerosol (SOA) due to the oxidized nature of these species as compared to other organics.

[3] Two widely studied areas in the United States with regard to atmospheric aerosol properties and composition include the Los Angeles Basin [Hidy et al., 1974; Grosjean and Friedlander, 1975; Husar et al., 1976, 1977; Blumenthal et al., 1978; Russell et al., 1983; McElroy and Smith, 1986; Russell and Cass, 1984, 1986; Kawamura and Kaplan, 1987; Wall et al., 1988; Pandis et al., 1992a, 1992b; Zhang et al., 
Table 1. Summary of CIRPAS Twin Otter Research Flights (RF) ${ }^{\mathrm{a}}$

\begin{tabular}{|c|c|c|c|c|}
\hline $\mathrm{RF}$ & Flight Date & Day of Week & Flight Time (UTC) & Mission Type \\
\hline 1 & $5 / 4 / 2010$ & Tuesday & $18: 01-21: 23$ & LA Basin \\
\hline 2 & $5 / 5 / 2010$ & Wednesday & $18: 04-22: 10$ & LA Basin \\
\hline 3 & $5 / 6 / 2010$ & Thursday & $19: 06-22: 59$ & LA Basin \\
\hline 4 & $5 / 7 / 2010$ & Friday & $18: 02-21: 57$ & LA Basin \\
\hline 5 & $5 / 10 / 2010$ & Monday & $19: 00-23: 05$ & LA Basin \\
\hline 6 & $5 / 12 / 2010$ & Wednesday & $17: 56-22: 08$ & LA Basin + Salton Sea \\
\hline 7 & $5 / 13 / 2010$ & Thursday & $18: 05-21: 54$ & LA Basin + Salton Sea \\
\hline 8 & $5 / 14 / 2010$ & Friday & $17: 59-22: 01$ & LA Basin \\
\hline 9 & $5 / 15 / 2010$ & Saturday & $18: 13-22: 13$ & LA Basin \\
\hline 10 & $5 / 18 / 2010$ & Tuesday & $18: 59-22: 53$ & San Joaquin Valley \\
\hline 11 & $5 / 19 / 2010$ & Wednesday & $18: 40-22: 45$ & LA Basin \\
\hline 12 & $5 / 20 / 2010$ & Thursday & $18: 53-22: 58$ & San Joaquin Valley + Cajon Pass \\
\hline 13 & $5 / 21 / 2010$ & Friday & $17: 57-22: 05$ & LA Basin + Cajon/Banning Passes \\
\hline $14^{\mathrm{b}}$ & $5 / 22 / 2010$ & Saturday & $18: 01-22: 12$ & San Joaquin Valley \\
\hline $15^{\mathrm{b}}$ & $5 / 24 / 2010$ & Monday & $18: 01-22: 03$ & LA Basin + Cajon Pass + Salton Sea \\
\hline 16 & $5 / 25 / 2010$ & Tuesday & $18: 27-22: 31$ & LA Basin + Cajon Pass + Salton Sea \\
\hline 17 & $5 / 27 / 2010$ & Thursday & $17: 59-21: 45$ & LA Basin \\
\hline 18 & $5 / 28 / 2010$ & Friday & $17: 58-22: 03$ & LA Basin \\
\hline
\end{tabular}

${ }^{\mathrm{a}}$ Local time $=$ UTC - seven hours.

${ }^{\mathrm{b}}$ WSOC measurements are not available.

1993; Chow et al., 1994; Hildemann et al., 1994a, 1994b, 1996; Eldering and Cass, 1996; Kleeman et al., 1999; Collins et al., 2000; Hughes et al., 2000; Neuman et al., 2003; Sardar et al., 2005; Vutukuru et al., 2006; Docherty et al., 2008; Hersey et al., 2011] and the San Joaquin Valley of California [Magliano et al., 1999; Schauer and Cass, 2000; Chow et al., 1992, 1993, 1996, 2006; Neuman et al., 2003; Sorooshian et al., 2008a]. While these studies have provided significant knowledge of regional aerosol characteristics, there remain important uncertainties with regard to organic aerosol composition and properties. There are particularly limited airborne measurements that have attempted to characterize the organic composition of aerosol in the Los Angeles Basin and downwind regions.

[4] Recent ground-based measurements in Pasadena, CA between May and September 2009 indicate that organics account for on average between 40 and $60 \%$ of the western Los Angeles Basin sub-micrometer aerosol mass [Hersey et al., 2011]. The oxidation state of the Pasadena organic aerosol, as expressed by the atomic oxygen:carbon ratio (O:C) was relatively stable ( 0.5) for periods of weeks with little difference at different times of the day. Water-soluble organics were estimated to account for between $\sim 30-70 \%$ of the organic mass [Wonaschütz et al., 2011]. Measurements by Peltier et al. [2007a] during the SOAR-1 campaign at Riverside, CA (summer 2005) showed that WSOC accounted for an approximate average of $52 \%$ of OC mass. Understanding the main sources and production mechanisms of WSOC in the Los Angeles Basin based on measurements at a fixed site has limitations owing to the meteorology of the Basin and the spatial distribution of the sources that lead to organic aerosol. For example, Wonaschütz et al. [2011] showed that the diurnal WSOC profile at Pasadena is governed by a combination of sea breeze winds, boundary layer height, and secondary production along the trajectory of air parcels in the Basin. Constraining the spatiotemporal nature of the amount, composition, and vertical distribution of particulate organic matter is critical as aerosol hygroscopicity in the region is largely governed by the organic mass fraction.
[5] In this work, detailed measurements of the nature and character of WSOC in the Los Angeles Basin and outflow regions were performed using both airborne and groundbased sampling during the California Research at the Nexus of Air Quality and Climate Change (CalNex) study in May 2010. Ground-based measurements of WSOC were carried out at two CalNex ground sites. Aircraft overpasses of the ground sites enabled a simultaneous comparison of WSOC in the same vertical column. We address the temporal and spatial variation of WSOC, with an aim to understand the factors that influence WSOC concentrations such as sources, transport and aging, topography, and meteorology. The structure of this paper is as follows: (i) overview of experimental methods; (ii) cumulative summary of WSOC measurements (e.g., vertical profiles, spatial maps, and relationships with other chemical and meteorological variables); (iii) detailed case studies of specific flights; (iv) conceptual model of the nature of WSOC in the study region; and (v) conclusions.

\section{Experimental Methods}

[6] A total of 18 flights were carried out with the Center for Interdisciplinary Remotely Piloted Aircraft Studies (CIRPAS) Twin Otter during the 2010 CalNex study between 4 May 2010 and 28 May 2010 (Table 1). WSOC was quantified during 16 flights, using a particle-into-liquid sampler (PILS; Brechtel Manufacturing Inc.) coupled to a Total Organic Carbon (TOC) Analyzer (Sievers Model 800) [Sullivan et al., 2006]. Briefly, particles smaller than $2.5 \mu \mathrm{m}$ in diameter are sampled by the PILS and passed immediately through an organic carbon denuder (Sunset Laboratory Inc.) to remove organic vapors. Particles are grown into droplets, collected by inertial impaction, and delivered through a $0.5 \mu \mathrm{m}$ PEEK (polyetheretherketone) liquid filter prior to entering a TOC analyzer for quantification of WSOC every $\sim 4 \mathrm{~s}$. Reported WSOC levels represent the difference between the measured and background concentrations, which were obtained by passing sampled air through a high efficiency particulate air (HEPA) filter. The overall measurement uncertainty is estimated to be approximately $10 \%$, with a minimum detection limit of $0.1 \mu \mathrm{g} \mathrm{C} \mathrm{m}^{-3}$. Synchronization 
Table 2. Summary of Measurements in the Vicinity of Banning Pass $\left(33.89^{\circ} \mathrm{N}, 33.98^{\circ} \mathrm{N} ;-116.77^{\circ} \mathrm{W},-116.99^{\circ} \mathrm{W}\right)^{\mathrm{a}}$

\begin{tabular}{|c|c|c|c|c|c|c|c|c|c|c|c|}
\hline $\mathrm{RF}$ & $\begin{array}{l}\text { Local } \\
\text { Time } \\
\text { of Day }\end{array}$ & $\begin{array}{c}\text { WSOC } \\
\left(\mu \mathrm{g} \mathrm{C} \mathrm{m}^{-3}\right)\end{array}$ & $\begin{array}{c}\text { PCASP } \\
\text { Volume } \\
\left(\mu \mathrm{m}^{3} \mathrm{~cm}^{-3}\right)\end{array}$ & $\begin{array}{c}\text { PCASP } \\
\left(\text { Number per } \mathrm{cm}^{3}\right)\end{array}$ & $\begin{array}{c}\text { DMA } \\
\text { Volume } \\
\left(\mu \mathrm{m}^{3} \mathrm{~cm}^{-3}\right)\end{array}$ & $\begin{array}{c}\text { DMA } \\
\left(\text { Number per } \mathrm{cm}^{3}\right)\end{array}$ & Alt (m) & $\mathrm{T}\left({ }^{\circ} \mathrm{C}\right)$ & RH (\%) & $\begin{array}{l}\text { Wind } \\
\text { Speed } \\
\left(\mathrm{m} \mathrm{s}^{-1}\right)\end{array}$ & $\begin{array}{c}\text { Wind } \\
\text { Direction } \\
\text { (deg) }\end{array}$ \\
\hline 1 & $12: 20$ & $0.41(0.12)$ & $3.66(1.38)$ & 952 (227) & $2.51(0.39)$ & 8031 (941) & $1036(158)$ & $20.8(1.8)$ & $23.9(2.4)$ & $5.5(1.8)$ & $256(17)$ \\
\hline 2 & $12: 30$ & $0.94(0.14)$ & & & $3.33(0.73)$ & 6942 (2019) & $992(156)$ & $19.2(1.6)$ & $36.3(3.1)$ & $7.5(2.3)$ & 252 (14) \\
\hline 2 & $14: 30$ & $1.21(0.17)$ & & & $4.19(0.46)$ & $7345(961)$ & 976 (139) & $21.0(1.5)$ & $30.6(2.6)$ & $8.2(1.9)$ & $261(14)$ \\
\hline 3 & $1: 30$ & $1.46(0.15)$ & $8.19(2.04)$ & $1367(125)$ & $4.31(0.60)$ & $5063(650)$ & 985 (149) & $17.6(1.7)$ & $41.2(5.7)$ & $6.9(2.4)$ & $256(14)$ \\
\hline 3 & $3: 10$ & $1.15(0.13)$ & $8.23(2.70)$ & $1443(181)$ & $4.72(1.49)$ & 6469 (99) & $1114(23)$ & $18.3(0.3)$ & $40.6(4.6)$ & $7.4(1.9)$ & $264(12)$ \\
\hline 4 & $12: 30$ & $0.37(0.03)$ & $1.54(1.04)$ & 269 (39) & $1.34(0.46)$ & $2480(130)$ & $1065(24)$ & $21.1(0.2)$ & $11.4(0.6)$ & $7.1(1.2)$ & 94 (13) \\
\hline 4 & $2: 20$ & $0.50(0.05)$ & & & $1.49(0.30)$ & $7720(1439)$ & $1068(36)$ & $22.8(0.3)$ & $14.3(1.3)$ & $2.8(1.6)$ & 217 (79) \\
\hline 6 & $2: 20$ & $0.41(0.07)$ & & & 3.27 (1.83) & 6029 (1194) & 1102 (69) & $17.6(0.8)$ & $25.7(2.5)$ & $5.6(1.5)$ & $258(24)$ \\
\hline 7 & $1: 30$ & $0.48(0.19)$ & $4.48(2.70)$ & 1037 (393) & $4.38(2.97)$ & 4967 (1341) & 1088 (49) & $19.3(0.8)$ & $25.3(3.5)$ & $5.1(2.3)$ & $177(79)$ \\
\hline 13 & $2: 40$ & $2.12(0.14)$ & $15.11(2.83)$ & 2437 (213) & $9.38(1.86)$ & $5416(352)$ & 1170 (19) & $17.2(0.3)$ & $54.5(1.8)$ & $8.7(2.6)$ & $264(16)$ \\
\hline 16 & $2: 40$ & $0.89(0.08)$ & $6.35(2.04)$ & $1604(385)$ & $4.38(0.31)$ & $5186(396)$ & $1058(81)$ & $16.0(1.0)$ & $39.2(3.1)$ & $7.3(1.9)$ & 267 (14) \\
\hline
\end{tabular}

${ }^{\text {a} D M A ~ d a t a ~ a r e ~ r e p o r t e d ~ s i n c e ~ P C A S P ~ d a t a ~ a r e ~ n o t ~ a v a i l a b l e ~ f r o m ~ F l i g h t s ~ 2, ~ 4, ~ a n d ~} 6$.

of WSOC measurements with the other aircraft instrument data described below takes into account well-documented liquid transport delays in the PILS instrument [Sorooshian et al., 2006].

[7] Contemporaneous with the airborne measurements, online $\mathrm{PM}_{2.5}$ WSOC measurements were carried out at two ground sites (Pasadena and Riverside) with the same instrument set-up as on the aircraft. The Pasadena CalNex ground site was located on the California Institute of Technology campus $\left(34.1406^{\circ} \mathrm{N},-118.1225^{\circ} \mathrm{W}\right)$. The Riverside site was located on the University of California-Riverside campus $\left(33.9719^{\circ} \mathrm{N},-117.3227^{\circ} \mathrm{W}\right)$. The sample inlet was $7 \mathrm{~m}$ above ground level at the Pasadena ground site, and $4.5 \mathrm{~m}$ above ground level at Riverside.

[8] Measurements of sub-micrometer inorganic and nonrefractory organic mass were obtained with an Aerodyne compact Time of Flight Aerosol Mass Spectrometer (C-ToFAMS) [Drewnick et al., 2005; Murphy et al., 2009]. AMS data used here include organic markers at specific mass-tocharge ratios $(\mathrm{m} / \mathrm{z})$ that serve as proxies for organics with a range of oxidation states: acid-like oxygenated organics $\left(\mathrm{m} / z 44=\mathrm{COO}^{+}\right)$, aliphatic and non-acid oxygenated organics $\left(\mathrm{m} / z \mathrm{z} 4 \mathrm{C}_{3} \mathrm{H}_{7}^{+}\right.$and $\left.\mathrm{C}_{2} \mathrm{H}_{3} \mathrm{O}^{+}\right)$, and aliphatic organics $(\mathrm{m} / z$ $57=$ $\mathrm{C}_{4} \mathrm{H}_{9}^{+}$) [McLafferty and Turecek, 1993; Zhang et al., 2005; Aiken et al., 2008; $\mathrm{Ng}$ et al., 2010]. Owing to the size cutoff of the AMS being smaller than the PILS (1 $\mu \mathrm{m}$ versus $2.5 \mu \mathrm{m}$ ), any mass ratios between WSOC and AMS measurements represent an upper limit.

[9] Particle size distribution measurements $\left(D_{p}=10 \mathrm{~nm}-\right.$ $800 \mathrm{~nm}$ ) on the aircraft were carried out with a cylindrical scanning differential mobility analyzer (DMA; TSI Model 3081) coupled to a condensation particle counter (CPC; TSI Model 3760), in addition to a passive cavity aerosol spectrometer probe (PCASP; $\left.D_{p}=100 \mathrm{~nm}-2.6 \mu \mathrm{m}\right)$. WSOC data are usually compared only to PCASP data in this study owing to similar size bins, while DMA data are used only when PCASP data were not available (Table 2). Subsaturated aerosol hygroscopicity measurements were provided by a differential aerosol sizing and hygroscopicity spectrometer probe at relative humidities of $74 \%$ and $92 \%$ and for dry diameters ranging between 150-225 nm (DASHSP; Brechtel Mfg Inc. [Sorooshian et al., 2008b]). Black carbon (BC) measurements were obtained using a single particle soot photometer instrument (SP2; Droplet Measurement Technologies).
[10] Ground-based gas $\left(\mathrm{CO}, \mathrm{O}_{3}\right)$ and aerosol $\left(\mathrm{PM}_{2.5}\right)$ measurements were obtained from existing monitoring stations throughout the Los Angeles Basin and outflow areas (see Figure 1) (http://www.arb.ca.gov/aqmis2/aqmis2.php; CARB IADAM Air Quality Data Statistics, 2010, http:// www.arb.ca.gov/adam). Additional hourly meteorological data were obtained from regional surface sites using the Mesowest Database [http://mesowest.utah.edu/index.html]. Solar radiation data were obtained from a ground site at Tonner Canyon $\left(33.948^{\circ} \mathrm{N},-117.822^{\circ} \mathrm{W}, \sim 410 \mathrm{~m}\right.$ altitude; Mesowest), which is centrally located within the Basin.

\section{Los Angeles Basin and Outflow Area Description}

[11] The metropolitan Los Angeles population exceeds 17 million and the Basin contains a complete spectrum of air pollution sources, including vehicular emissions, cooking, biomass burning, industrial activity, agricultural activity, and marine shipping. The Los Angeles Basin is bordered on three sides by mountainous terrain and by the Pacific Ocean on the southwestern side (Figure 1). Transport of pollutants in the Los Angeles Basin is governed largely by sea breeze and mountain flows [Lu and Turco, 1995]. Average monthly wind roses are shown in auxiliary material Figure $\mathrm{S} 1$ for the month of May across the study region and representative wind directions are shown in Figure 1. ${ }^{1}$ The general wind pattern in the region during the period of time that flights occurred was as follows: westerly and southwesterly winds transporting air from the western edge of the Basin toward the eastern edge, where air is funneled out of narrow passes into desert regions. The two main passes are to the north through the Cajon Pass toward Victorville and Barstow and to the east via the Banning Pass.

[12] During CalNex, fine particle number concentrations were typically highest $\left(>10,000 \mathrm{~cm}^{-3}\right)$ at the western side of the Los Angeles Basin (longitude: $118.05^{\circ} \mathrm{W}-118.3^{\circ} \mathrm{W}$ ), especially in the Long Beach area owing to major point sources. Fine particle number concentrations generally decreased as a function of distance eastward, while PCASP particle number and volume concentrations exhibited the opposite behavior and typically reached peak levels near the northern and eastern edges of the Basin. This can be explained by aging processes along the typical sea breeze

\footnotetext{
${ }^{1}$ Auxiliary materials are available in the HTML. doi:10.1029/ 2011JD016674
} 


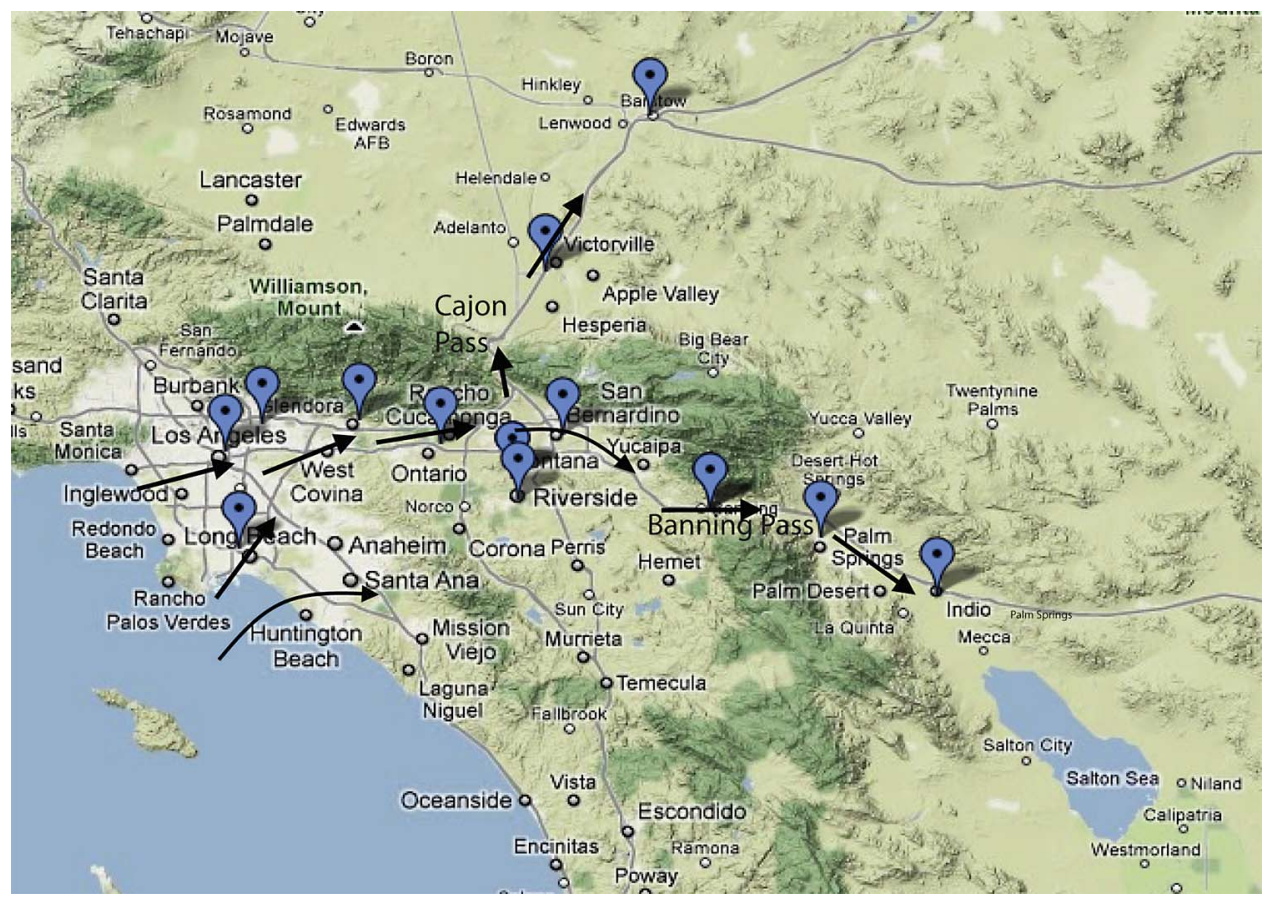

Figure 1. Terrain map of the Los Angeles Basin and outflow regions including Banning Pass, which funnels air out toward areas including Indio and the Salton Sea, and the Cajon Pass, which transports air toward Victorville and Barstow. Blue markers correspond to ground stations (http://www.arb.ca. gov/aqmis2/aqmis2.php) at which gas and $\mathrm{PM}_{2.5}$ data were obtained. Black arrows correspond to the typical wind directions during the durations of the flights; specific monthly averaged wind roses across the study region are shown in auxiliary material Figure S1.

trajectory leading to the growth of particles into the size range of the PCASP $\left(D_{p}>100 \mathrm{~nm}\right)$.

\section{WSOC Distributions}

\subsection{Spatial WSOC Distribution}

[13] Figure 2 shows the cumulative spatial distribution of WSOC concentration measured on the Twin Otter during
May 2010. Average levels in specific portions of the region are shown in Figure 3a. WSOC was fairly well-correlated with particle number concentration $\left(\mathrm{r}^{2}=0.49\right.$; slope $=$ $\left.0.85 \mathrm{ng} \mathrm{C} \mathrm{m}^{-3} / \mathrm{cm}^{-3} ; n=34655\right)$ and volume concentration $\left(\mathrm{r}^{2}=0.53\right.$; slope $\left.=0.12 \mu \mathrm{g} \mathrm{C} \mathrm{m}^{-3} /\left(\mu \mathrm{m}^{3} \mathrm{~cm}^{-3}\right) ; n=33975\right)$, as measured by the PCASP. The highest WSOC concentrations were consistently observed in the Los Angeles Basin, as compared to desert outflow regions and the San

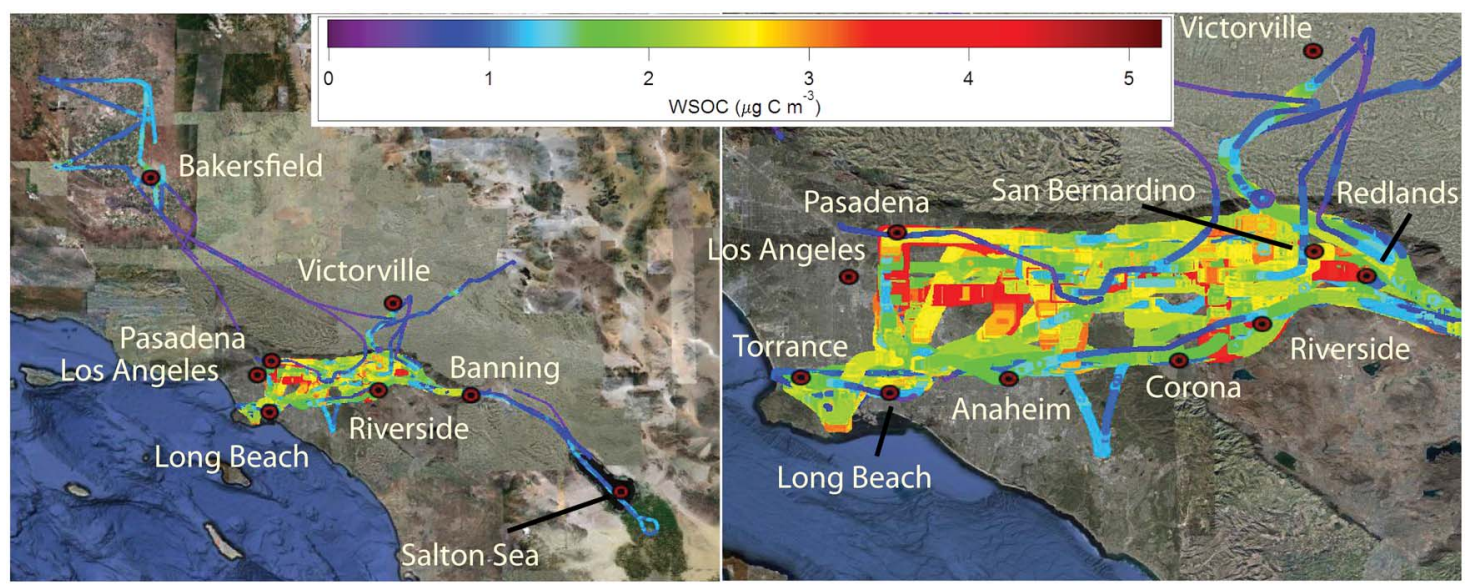

Figure 2. (left) Spatial distribution of WSOC concentrations during the CalNex campaign in the San Joaquin Valley, the Los Angeles Basin, and outflow regions extending north through the Cajon Pass and east through the Banning Pass toward Indio and the Salton Sea. (right) Close-up of WSOC in the Los Angeles Basin. 

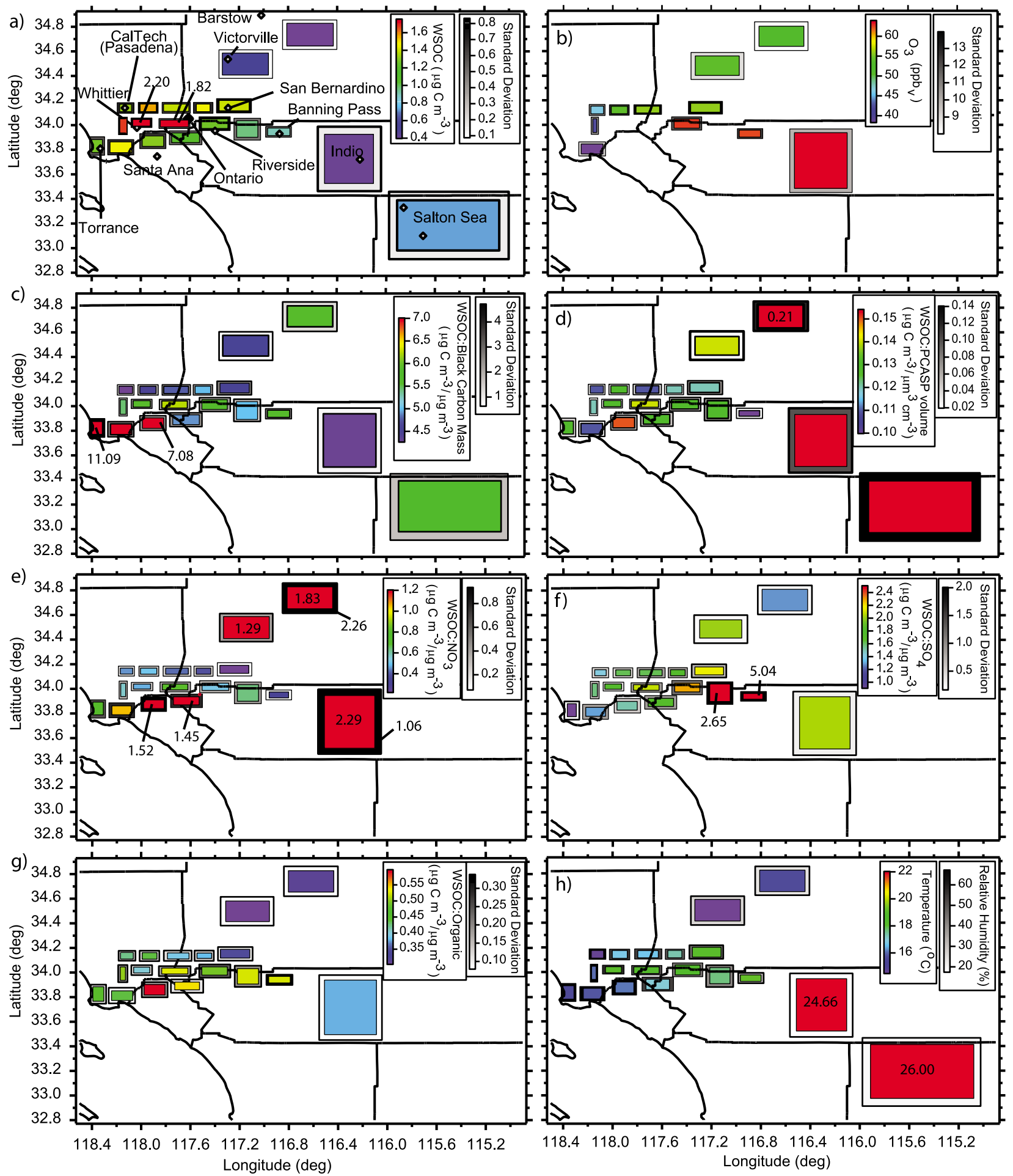

Figure 3. Cumulative spatial averages of (a) WSOC, (b) surface $\mathrm{O}_{3}$ concentration, (c) WSOC:BC, (d) WSOC:PCASP volume concentration, (e) WSOC:nitrate, (f) WSOC:sulfate, (g) WSOC:organic, and (h) ambient temperature and RH. Numbers in boxes correspond to true values that exceed the range shown in color bars. Sizes of the boxes correspond to the geographic area within which the data were averaged. City labels are included in Figure 3a.

Joaquin Valley, reaching values as high as $5.3 \mu \mathrm{g} \mathrm{C} \mathrm{m}^{-3}$. High concentrations were often observed along the northsouth corridor extending between Pasadena and the downtown Los Angeles area, coincident with the highest levels of BC, $\mathrm{CO}$, and $\mathrm{m} / z 57\left(>0.3 \mu \mathrm{g} \mathrm{m}^{-3},>0.35 \mathrm{ppm}_{\mathrm{v}},>80 \mathrm{ng} \mathrm{m}^{-3}\right.$, respectively). Comparable or higher concentrations were also observed during some flights on the eastern side of the Basin near San Bernardino and Redlands. The lowest concentrations 

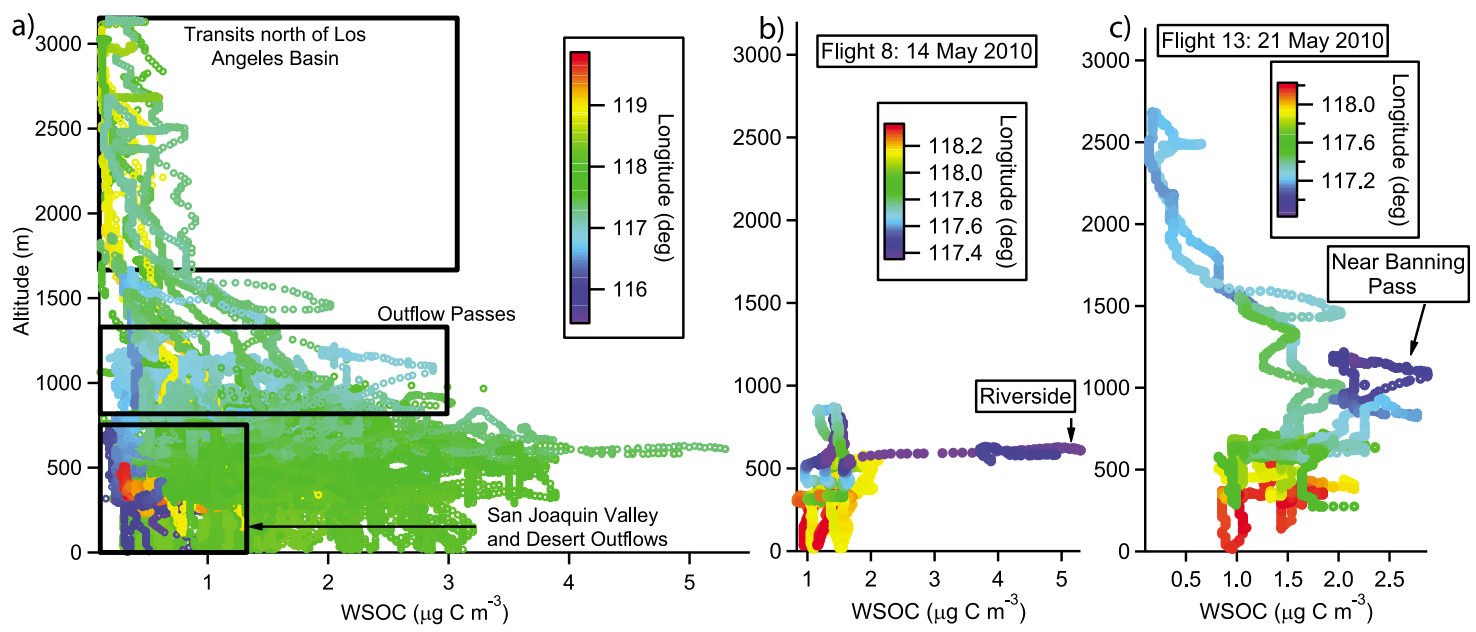

Figure 4. (a) Vertical profile of WSOC mass concentrations during 16 flights over the spatial domain shown in Figure 1. The majority of the data collected below $1 \mathrm{~km}$ are from the Los Angeles Basin, with the minority of the yellow-red and blue markers corresponding to San Joaquin Valley and outflow areas to the east of the Basin, respectively. The majority of the markers near $1 \mathrm{~km}$ correspond to transits through outflow-passes (i.e., Banning Pass and Cajon Pass), while higher altitudes correspond to transits north of the Los Angeles Basin. (b and c) Examples of vertical profiles during two flights in the Los Angeles Basin showing that the highest WSOC levels were observed above the first few hundred meters. The maximum WSOC level during Flight 8 corresponded to a local fire plume, while the peak WSOC level in Flight 13 was observed over the eastern edge of the Basin near Banning Pass.

of WSOC in the Los Angeles Basin were usually observed near Torrance when the dominant wind direction was westerly from the ocean (i.e., upwind of major emissions sources in Long Beach), and to the southeast/east of the Puente and Chino Hills, which serve as a barrier to the transport of pollution from the western side of the Basin. Outflow regions were characterized by lower WSOC levels than those observed in the Basin mainly owing to dilution during urban plume transport and a lack of significant WSOC sources in the desert. The general west-to-east transect of highest WSOC levels coincided with the average westerly/southwesterly wind patterns during the period of flights, with increases from the western side of the Basin near downtown Los Angeles toward maximum levels near Whittier, then decreasing to the northeast near San Bernardino. Smoke plumes were occasionally intercepted in the Los Angeles Basin, usually near the eastern side in the vicinity of Riverside, owing to small-scale fires. These plumes resulted in the highest WSOC concentrations during the respective flights, with one being the highest of the campaign (maximum levels observed in separate fire plumes: $1.7 \mu \mathrm{g} \mathrm{C} \mathrm{m}^{-3}$, Flight 6; $5.3 \mu \mathrm{g} \mathrm{C} \mathrm{m}^{-3}$, Flight $8 ; 1.8 \mu \mathrm{g} \mathrm{C} \mathrm{m}^{-3}$, Flight $12 ; 1.6 \mu \mathrm{g} \mathrm{C} \mathrm{m}^{-3}$, Flight 18). Chemical ratios that can be used to trace secondary production (e.g., WSOC:CO; WSOC:BC) become perturbed in these cases owing to primary production (i.e., direct emission) of WSOC in these fresh plumes.

[14] A number of flights focused on Banning Pass, owing to the role of this area as an exit for the Basin pollution. Table 2 shows a summary of all the WSOC measurements in this area with relevant meteorological information. Out of eleven flight legs through this outflow-pass, nine were characterized by westerly winds and higher WSOC levels than periods with easterly winds. For example, during Flight 4 the first transect was characterized by easterly winds and lower concentrations of WSOC and particle concentration.
Approximately two hours later, winds shifted to be westerly resulting in enhancements in WSOC $\left(0.37\right.$ to $\left.0.50 \mu \mathrm{g} \mathrm{C} \mathrm{m}^{-3}\right)$ and fine particle number concentration $\left(2480\right.$ to $\left.7720 \mathrm{~cm}^{-3}\right)$. Of the other parameters shown in Table 2, WSOC was best correlated with RH and PCASP particle volume concentration $\left(r^{2}=0.79\right.$ for both $)$.

\subsection{Vertical WSOC Distribution}

[15] The airborne measurements were usually conducted below an altitude of $1 \mathrm{~km}$ in the Los Angeles Basin and San Joaquin Valley and at higher altitudes through the outflowpasses (Figure 4a). On 11 of the 16 flights, WSOC exhibited its highest concentration above $500 \mathrm{~m}$, usually near the eastern end of the Basin by Riverside, San Bernardino, and Banning Pass. Two representative flights demonstrating this behavior are shown in Figures $4 \mathrm{~b}$ and $4 \mathrm{c}$, where WSOC peaks between 600 and $1100 \mathrm{~m}$ in altitude near Banning Pass and Riverside. The maximum concentration during Flight $8\left(5.3 \mu \mathrm{g} \mathrm{C} \mathrm{m}^{-3}, 14\right.$ May 2010) corresponded to a Riverside fire plume and was the highest Twin Otter WSOC measurement of the entire CalNex field study. A cluster of points in Figure 4a (color-coded as blue and yellow-orange) are relatively lower in WSOC concentration than the rest below $1 \mathrm{~km}$ as they are from the San Joaquin Valley and outflow areas.

[16] Multiple pollution layers have been observed aloft in this region in past airborne measurements [Blumenthal et al., 1978; McElroy and Smith, 1986; Collins et al., 2000]. These layers arise by horizontal and vertical displacement of the morning inversion layer and orographic uplift $[L u$ and Turco, 1995]. It is possible that such layers, which can undergo continued chemical processing while separated from the mixing layer, contribute to surface concentrations through turbulent mixing as the boundary layer deepens [Husar et al., 

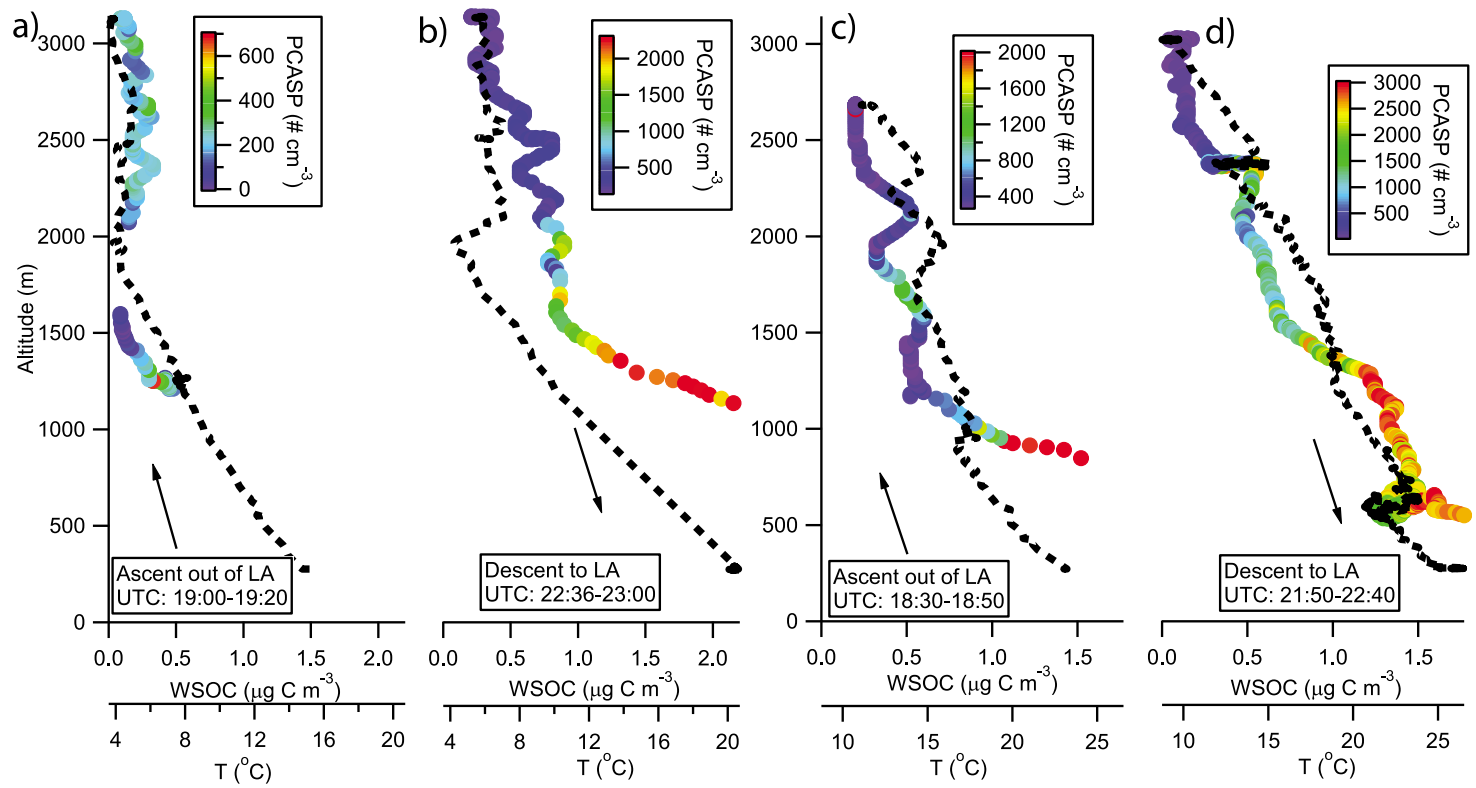

Figure 5. Vertical profiles of WSOC during two flights: (a and b) Flight 10 on 18 May 2010 and (c and d) Flight 12 on 20 May 2010. Colored markers correspond to WSOC and dashed black lines represent ambient temperature. Local time $=\mathrm{UTC}-$ seven hours.

1977; Blumenthal et al., 1978]. Vertical profiles of WSOC were obtained during two flights up to an altitude of approximately $3.2 \mathrm{~km}$ (Figure 5). The ascents and descents occurred at the northern edge of the Basin. These profiles offer a direct comparison of WSOC separated by $2-4 \mathrm{~h}$ of aging time. The ascents out of Los Angeles at the beginning of the flights (Figures $5 \mathrm{a}$ and $5 \mathrm{c}$ ) were characterized by a decrease in WSOC with altitude until a point where a series of vertical layers became evident with enhanced WSOC levels and PCASP particle number concentrations. The descents into the Basin (Figures $5 \mathrm{~b}$ and $5 \mathrm{~d}$ ) more than two hours later exhibited systematically larger WSOC and PCASP number concentrations in the bottom $1.5 \mathrm{~km}$ above the surface with similar layers of WSOC enrichment at higher altitudes. This is likely due to continuous emissions during the daytime and higher photochemical activity occurring to generate more WSOC.

[17] To identify the level of vertical WSOC variation in the mixing layer, simultaneous ground and airborne measurements in the same vertical column are compared at Pasadena (Figure 6a) and Riverside (Figure 6b). A total of 13 and 12 simultaneous measurements were conducted in Pasadena and Riverside, respectively, between 11:00-15:30 (LT). The airborne measurements during the overpasses were conducted within the mixing layer at altitudes between 500 $800 \mathrm{~m}$. At both sites, WSOC levels were generally higher aloft, and the difference is more evident in Pasadena. The greatest enhancements aloft relative to ground measurements at both sites were coincident with the highest ratios of $\mathrm{RH}$ aloft relative to at the surface, which is most evident at Riverside. The average RHs during the overpasses at Pasadena and Riverside were $67 \pm 10 \%(\max =78 \%)$ and $52 \pm 9 \%(\max =65 \%)$, respectively. This may be indicative of production of WSOC by processes that are more efficient as a function of increasing aerosol-phase water. High RHs $(>70 \%)$ have been shown to coincide with enhanced partic- ulate WSOC and organic acid concentrations owing to more effective partitioning of these species to the aerosol phase and multiphase chemistry [e.g., Hennigan et al., 2008b, 2009; Ervens and Volkamer, 2010, Sorooshian et al., 2010]. In addition, direct photolytic processing has also been suggested to be an important mechanism to generate SOA in particles residing in humid air [Bateman et al., 2011].

[18] Vertical profiles of ratios of WSOC to PCASP particle volume concentration and AMS organic mass are shown in Figure 7. The range of the average WSOC:particle volume concentration ratio (Figure 7a) was between 0.11 and 0.19 between the surface and $3.2 \mathrm{~km}$, while the WSOC:organic ratio (Figure $7 \mathrm{~b}$ ) ranged widely between 0.26 and 0.63 . Both ratios exhibit variable behavior as a function of altitude, with an average reduction from the surface to $\sim 800 \mathrm{~m}$, and with maximum values occurring at altitudes exceeding $1500 \mathrm{~m}$. The large variability in these ratios is largely a result of day-to-day variability; however, the absolute range of the ratios is indicative of WSOC being a significant component of the aerosol from the surface up to $3.2 \mathrm{~km}$.

\subsection{WSOC Ratios to Other Aerosol Mass and Volume Measurements}

[19] To gain more insight into the relative importance of WSOC to the total aerosol budget and the sources and sinks of WSOC, the ratios of WSOC to other aerosol parameters are examined in Figures 3 and 8. Despite the existence of vertical gradients in aerosol composition and mass, it is useful to constrain airborne-measured WSOC with simultaneous ground-based $\mathrm{PM}_{2.5}$ measurements $\left(\mathrm{PM}_{2.5}\right.$ was not quantified on the Twin Otter). For the limited sites at which $\mathrm{PM}_{2.5}$ measurements were available within the Basin, WSOC contributed typically between 6 and $11 \%$ to $\mathrm{PM}_{2.5}$ mass. Note that converting WSOC to an organic mass equivalent concentration requires a conversion factor, which was previously assumed to be $\sim 1.8$ for the region [Docherty 

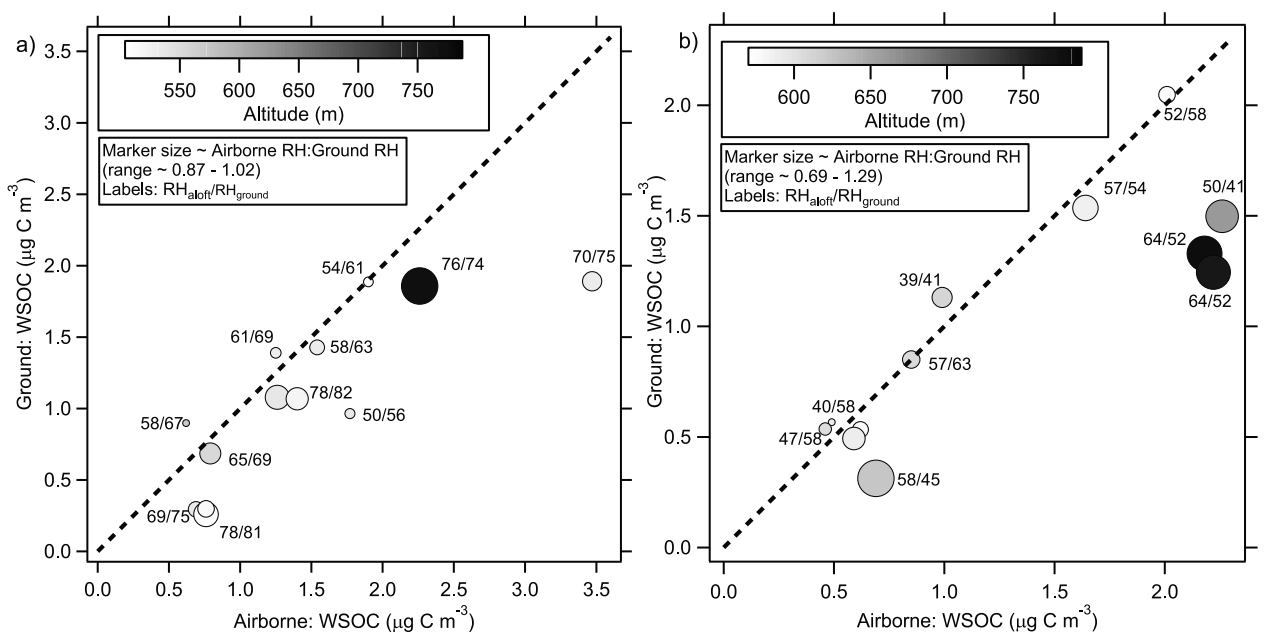

Figure 6. Comparison of simultaneous ground and airborne WSOC measurements in the same vertical column at (a) Pasadena and (b) Riverside.

et al., 2008]. The ratio of WSOC to $\mathrm{PM}_{2.5}$ was highest in the western portion of the Los Angeles Basin near Long Beach, downtown Los Angeles, and Glendora (0.10-0.11) and was lowest near Banning Pass $(\sim 0.06)$ owing partly to the major enhancement in ammonium nitrate levels near the eastern side of the Basin. The closest measure of how WSOC contributes to total $\mathrm{PM}_{2.5}$ using aircraft measurements is the comparison to PCASP volume concentration, where the PCASP measures particles in a similar size range as the PILSTOC $(<2.5 \mu \mathrm{m})$. The WSOC:PCASP volume ratio (Figure $3 \mathrm{~d}$ ) was typically between $\sim 0.1-0.15 \mu \mathrm{g} \mathrm{C} \mathrm{m}^{-3} /\left(\mu \mathrm{m}^{3} \mathrm{~cm}^{-3}\right)$ in the Los Angeles Basin, while higher average values were observed in the outflow regions. Ratios reached an average of $0.30 \pm 0.14$ near the Salton Sea to the east of the Basin and
$0.21 \pm 0.12$ near Barstow to the northeast of the Basin. As a basis for comparison, the ratio of WSOC to fine particle volume concentration was 0.12 and $0.10-0.22 \mu \mathrm{g} \mathrm{C} \mathrm{m}^{-3} /$ $\left(\mu \mathrm{m}^{3} \mathrm{~cm}^{-3}\right)$ in non-biomass and biomass burning plumes, respectively, in the northeastern United States [Sullivan et al., 2006; Peltier et al., 2007b]. An increase in this ratio can be due to a variety of reasons including losses in other aerosol components (e.g., nitrate volatilization), increased production of WSOC during transport, local sources such as fires, or entrained air masses from aloft that are enriched with WSOC relative to other aerosol components.

[20] Examining the variation of relative concentrations of WSOC and other particle and gas-phase constituents along the sea breeze trajectory from west to east provides insight
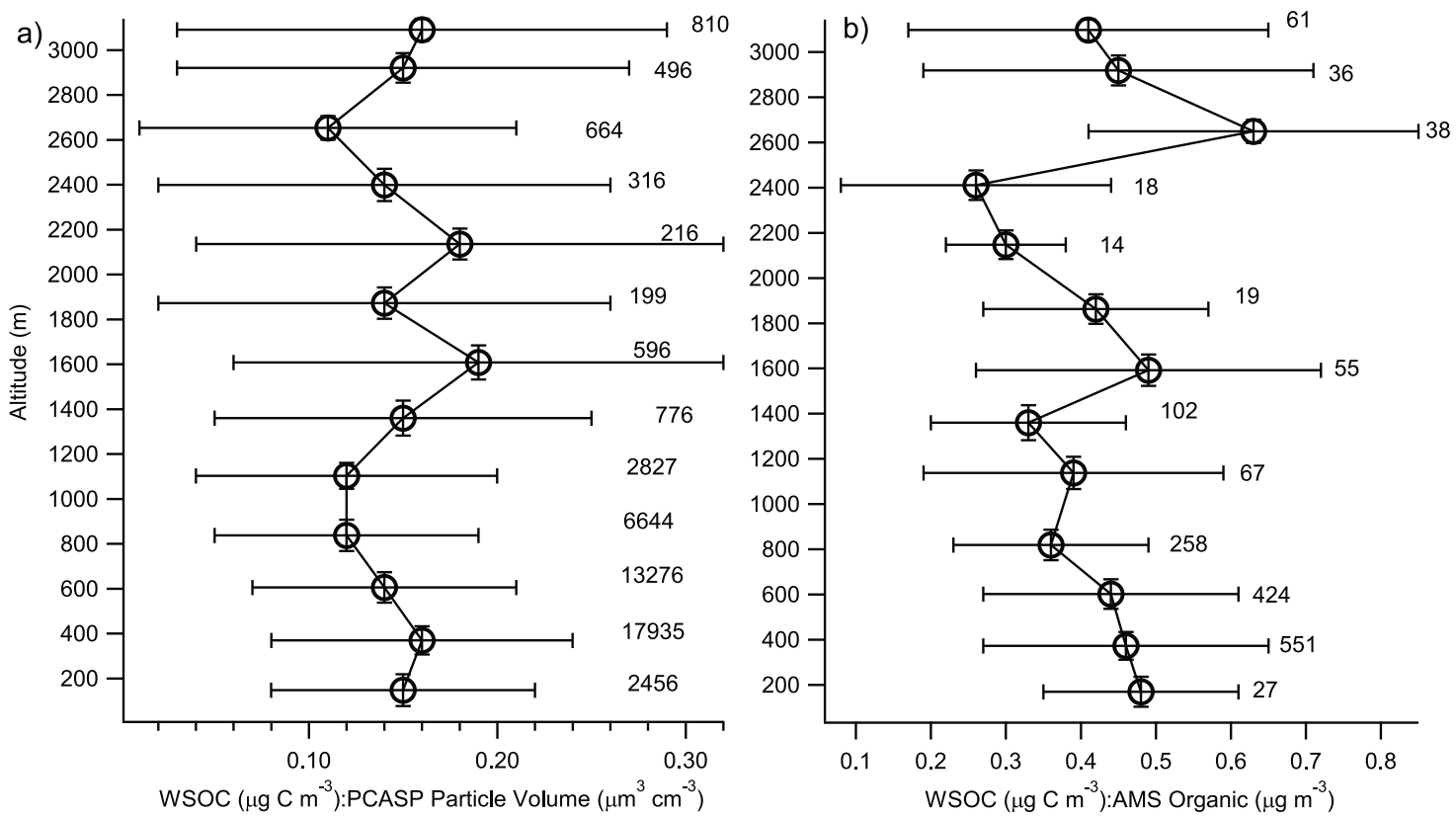

Figure 7. Vertical distribution of (a) the ratio of WSOC to PCASP particle volume concentration (data from all flights) and (b) the ratio of WSOC to total AMS non-refractory organic aerosol mass (Flight 11, 13, 16-18). Numbers beside each point in each panel correspond to the sample size. 


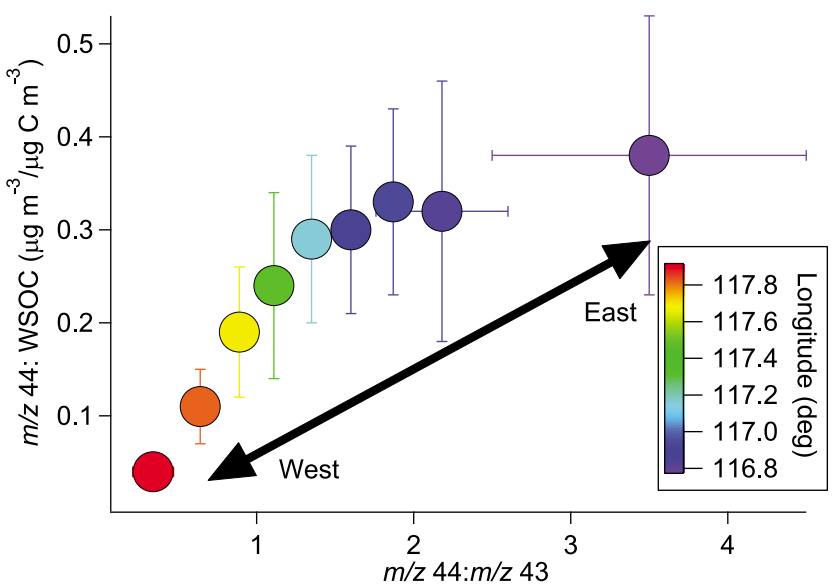

Figure 8. Ratio of $\mathrm{m} / \mathrm{z} 44: \mathrm{WSOC}$ as a function of $\mathrm{m} / \mathrm{z}$ 44:43. Markers are color-coded with longitude where red corresponds to western side of the Los Angeles Basin and purple corresponds to outflow desert regions to the east of the Basin.

into the relative importance of volatilization and secondary formation of WSOC (Figure 3). The highest $\mathrm{O}_{3}$ levels were observed farther inland and were highest in the outflows to the east of the Basin (Figure 3b). This is indicative of increased photochemical processing during sea breeze transport of air masses from the coast to the desert. This would likewise favor secondary production of WSOC. Black carbon is a primary species and thus an increase in the WSOC:BC ratio is a tracer for secondary production. This ratio was highest near the southwestern portion of the study region, presumably owing to the low levels of $\mathrm{BC}$ in marine air and upwind of major BC sources in the Basin (Figure $3 \mathrm{c}$ ). This ratio did not show any clear trend as a function of downwind distance, likely a result of the abundance of $\mathrm{BC}$ and organic aerosol sources in the Basin, including the fires observed on the eastern side of the Basin. Unlike the majority of the Basin, there are fewer BC sources along trajectories to the east of the outflow channels; WSOC:BC initially decreases and then increases owing possibly to a combination of WSOC volatilization initially and secondary production afterwards.

[21] The contribution of WSOC to total non-refractory organic mass was highest near the southwestern portion of the Los Angeles Basin (up to $\sim 60 \%$ just north of Santa Ana) and lowest in the desert outflow regions $(<40 \%)$ (Figure $3 \mathrm{~g}$ ). Along the sea breeze trajectory on the northern side of the Basin, the WSOC:Organic ratio tended to increase toward Banning Pass reaching an average value of $53 \pm 34 \%$. Recent studies have utilized $\mathrm{m} / \mathrm{z} 44$ and $\mathrm{m} / \mathrm{z} 43$ [e.g., $\mathrm{Ng}$ et al., 2010] to track the aging of organic aerosol in the atmosphere. The ratio of $\mathrm{m} / \mathrm{z} 44: 43$ provides information about the chemical functionality of oxygenated organic aerosol (OOA), with higher values indicative of a higher state of oxidation. Wonaschütz et al. [2011] examined the ratio of $\mathrm{m} / \mathrm{z} 44:$ WSOC as a function of $\mathrm{m} / \mathrm{z}$ 44:43 during the PACO campaign as a way of understanding how the composition of the WSOC fraction of the aerosol changed with photochemical age. Aircraft measurements in Figure 8 show that the ratio of $m / z 44:$ WSOC increased as a function of $m / z 44: 43$, with increases in both ratios as a function of longitude (higher values to the east). This is consistent with a shift from semi-volatile OOA components to more lowvolatility OOA components as a function of photochemical aging. The immediate sharp increase in $\mathrm{m} / \mathrm{z} 44$ :WSOC followed by a plateau is consistent with the findings of $\mathrm{Ng}$ et al. [2010] and previous measurements during PACO [Wonaschütz et al., 2011]. It is noted that $\mathrm{m} / \mathrm{z} 44$ levels reached as high as $\sim 1.8 \mu \mathrm{g} \mathrm{m}^{-3}$, which is roughly similar to peak levels observed in Pittsburgh during September (up to $\sim 1.2 \mu \mathrm{g} \mathrm{m}^{-3}$ [Zhang et al., 2005]), Tokyo in August (up to $\sim 2.29 \mu \mathrm{g} \mathrm{m}^{-3}$ [Takegawa et al., 2007]), but less than that in Tokyo during the summer (up to $\sim 3.5 \mu \mathrm{g} \mathrm{m}^{-3}$ ) [Kondo et al., 2007].

[22] More insight into the secondary production of organics arises from the ratio of WSOC: $\mathrm{SO}_{4}^{2-}$ (Figure 3f) as a function of distance eastward from the western end of the Basin where the highest $\mathrm{SO}_{4}^{2-}$ levels were observed, owing to marine shipping sources and other major point sources near the coast. The WSOC: $\mathrm{SO}_{4}^{2-}$ ratio ranged between 0.9 and 5.0 in the study region, which is greater than the cumulative average ratio $(\sim 0.55)$ observed by Peltier et al. [2007b] in the northeastern United States. The peak WSOC: $\mathrm{SO}_{4}^{2-}$ ratios between Riverside and Banning are coincident with an area with intense ammonium nitrate production owing largely to the influence of agricultural activity as a source of $\mathrm{NH}_{3}$, including animal husbandry operations. Ammonium nitrate production results in enhanced aerosol hygroscopicity and aerosol-phase water, which would promote more partitioning of WSOC to the aerosol phase and both multiphase chemistry and photolytic processing to produce WSOC [Hennigan et al., 2008a; Ervens and Volkamer, 2010; Sorooshian et al., 2010; Bateman et al., 2011]. In addition, WSOC may have been produced in the emissions from the agricultural activity. The WSOC: $\mathrm{SO}_{4}^{2-}$ ratio decreased immediately downwind of Banning by an average factor of nearly 2.5 and this may be due to volatilization of WSOC (note that $\mathrm{SO}_{4}^{2-}$ is not volatile), which is consistent with the reduction in the WSOC: $\mathrm{BC}$ ratio (by an average factor of $\sim 2$ ) in the same area. Production of $\mathrm{SO}_{4}^{2-}$ in this area can likely be ruled out owing to the low RHs, high temperatures, and lack of aqueous-phase chemistry to produce $\mathrm{SO}_{4}^{2-}$ during afternoons (Table 2). The average $\mathrm{RH}$ during traverses through Banning Pass ranged between 11 and 55\%.

[23] Reductions in aerosol-phase water, such as what happens when air is advected from the Basin to the desert outflows, promotes re-partitioning of WSOC to the gas phase [Hennigan et al., 2008b; 2009]. Lower amounts of the aerosol-phase water are associated with reduced RH and aerosol hygroscopicity. As shown in Figure 3h, the average temperature generally increases from west to east, and vice versa for average RH. The sub-saturated hygroscopicity of the regional aerosol decreased in the outflows, largely owing to ammonium nitrate volatilization. The average hygroscopic growth factor $\left(D_{p, w e t} / D_{p, d r y}\right)$ at an RH of $92 \%$ for fine aerosol was $1.72 \pm 0.25$ in the Basin and $1.57 \pm 0.19$ in the desert outflows. To further examine the likelihood that volatilization is a sink for WSOC downwind of the Los Angeles Basin, the ratio of WSOC: $\mathrm{NO}_{3}^{-}$is also examined (Figure 3e), as $\mathrm{NO}_{3}^{-}$is vulnerable to evaporation. The range of this ratio was $0.2-2.3$, within which are values observed in Mexico City $(\sim 0.2-1.0)$ 

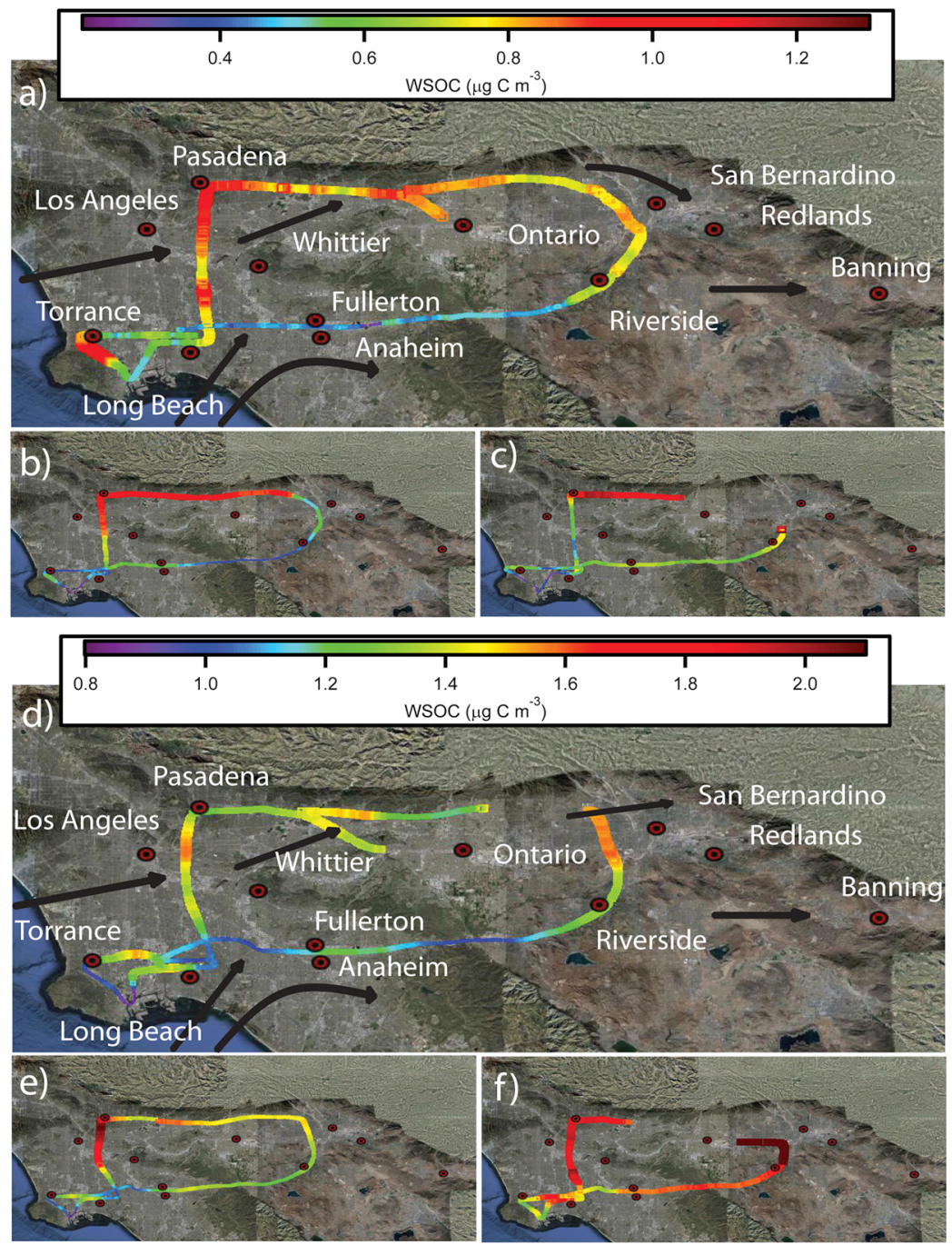

Figure 9. Spatial maps of WSOC during three successive Basin loops in Flight 5 on 10 May 2010 ((a) UTC = 19:00-20:30, (b) 20:30-21:50, and (c) 21:50-23:00) and in Flight 8 on 14 May $2010((\mathrm{~d}) \mathrm{UTC}=$ 18:00-19:30, (e) 19:30-20:50, and (f) 20:50-22:00). Black arrows in Figures 10a and 10d correspond to the typical wind directions during the duration of the two flights as determined by wind roses obtained from the Mesowest Database [http://mesowest.utah.edu/index.html]. Local time = UTC - seven hours.

[Hennigan et al., 2008a] but much less than the cumulative average ratio $(>30)$ observed in the northeastern United States [Peltier et al., 2007b]. AMS $\mathrm{NO}_{3}^{-}$mass concentrations are typically highest at San Bernardino $\left(6.08 \pm 5.87 \mu \mathrm{g} \mathrm{m}^{-3}\right.$ for the box labeled with this city in Figure 3) and they decrease significantly immediately downwind of the outflow-passes. As a result, the WSOC: $\mathrm{NO}_{3}^{-}$ratio increased sharply in the outflows (greater than a factor of six), in contrast to the WSOC: $\mathrm{SO}_{4}^{2-}$ ratio. This indicates that WSOC is less sensitive to volatilization as compared to ammonium nitrate. Such results are consistent with observations in Mexico City [Hennigan et al., 2008a].

[24] The general picture drawn in Figure 3 involves the following: (i) the western Basin is an important anthropogenic source for WSOC and precursors; and (ii) pollutants are transported to the eastern side of the Basin and through outflow-passes with the sea breeze, with aerosol aging processes during this time including dilution, secondary formation of WSOC, and volatilization of some fraction of
WSOC. The increasing temperatures (decreasing $\mathrm{RH}$ ) and reduction of aerosol hygroscopicity and aerosol-phase water in the outflows is likely responsible for the loss of some WSOC mass.

\section{Case Studies in the Los Angeles Basin}

\subsection{Basin Loops}

[25] Two weekdays characterized by different meteorological conditions and nearly identical flight paths in the Los Angeles Basin are examined to study the sensitivity of the spatiotemporal distribution of WSOC to meteorology (Figure 9). Flight 5 on 10 May 2010 was characterized by higher wind speeds, higher ambient temperature, and lower incident solar radiation as compared to Flight 8 on 14 May 2010 during the duration of the flights (Table 3). Flight 5 was characterized by cloudy conditions in the Basin during the time span of the flight, unlike Flight 8 . The aircraft flew at an altitude of approximately $\sim 300-600 \mathrm{~m}$ both 
Table 3. Average Values of Meteorological and Aerosol Parameters During Los Angeles Basin Loops During Five Flights ${ }^{\mathrm{a}}$

\begin{tabular}{|c|c|c|c|c|c|c|c|c|c|c|}
\hline & UTC Time & $\mathrm{T}\left({ }^{\circ} \mathrm{C}\right)$ & RH (\%) & $\begin{array}{l}\text { Wind } \\
\left(\mathrm{m} \mathrm{s}^{-1}\right)\end{array}$ & $\begin{array}{c}\text { CPC } \\
\left(\text { Number per } \mathrm{cm}^{3}\right)\end{array}$ & $\begin{array}{c}\text { PCASP } \\
\left(\text { Number per } \mathrm{cm}^{3}\right)\end{array}$ & $\begin{array}{c}\text { WSOC } \\
\left(\mu \mathrm{g} \mathrm{C} \mathrm{m}^{-3}\right)\end{array}$ & $\mathrm{O}_{3}(\mathrm{ppb})$ & $\begin{array}{c}\text { WSOC:BC } \\
\left(\mu \mathrm{g} \mathrm{C} \mathrm{m}^{-3} /\right. \\
\left.\mu \mathrm{g} \mathrm{m}^{-3}\right)\end{array}$ & $\begin{array}{c}\text { Solar } \\
\text { Radiation } \\
\left(\mathrm{W} \mathrm{m}^{-2}\right)\end{array}$ \\
\hline \multirow[t]{3}{*}{ Flight 5} & Loop 1 (19:00-20:30) & $13.3(1.1)$ & $62.5(6.5)$ & $4.8(1.8)$ & 9583 (4649) & $754(312)$ & $0.72(0.19)$ & $52.3(8.4)$ & $5.6(0.8)$ & $896(173)$ \\
\hline & Loop $2(20: 30-21: 50)$ & $13.7(1.1)$ & $61.2(5.7)$ & $5.8(1.5)$ & $11025(4466)$ & $774(393)$ & $0.66(0.28)$ & $53.7(9.7)$ & $6.2(1.8)$ & $816(71)$ \\
\hline & Loop $3(21: 50-23: 00)$ & $13.8(1.0)$ & $60.3(6.1)$ & $6.3(1.8)$ & $10747(4386)$ & $642(354)$ & $0.67(0.25)$ & $53.9(9.6)$ & $8.8(5.4)$ & $728(185)$ \\
\hline \multirow[t]{3}{*}{ Flight 8} & Loop $1(18: 00-19: 30)$ & $14.8(0.5)$ & $70.4(3.0)$ & $2.6(1.0)$ & $9664(2517)$ & $1372(264)$ & $1.33(0.12)$ & 50.8 (11.9) & $5.0(1.1)$ & $1066(40)$ \\
\hline & Loop 2 (19:30-20:50) & $16.7(0.7)$ & $62.8(4.6)$ & $3.3(1.0)$ & $12299(3574)$ & $1575(294)$ & $1.57(0.27)$ & $53.3(11.6)$ & $4.5(2.4)$ & $1064(43)$ \\
\hline & Loop 3 (20:50-22:00) & $17.7(1.26)$ & $60.8(6.4)$ & $3.8(1.0)$ & $14723(3514)$ & $1641(301)$ & $1.75(0.15)$ & $55.8(11.8)$ & $6.9(3.9)$ & $985(85)$ \\
\hline \multirow[t]{2}{*}{ Flight 9} & Loop $1(18: 20-20: 05)$ & $18.1(2.7)$ & $61.2(14.5)$ & $3.2(1.5)$ & $9953(3706)$ & $1751(422)$ & $2.61(0.55)$ & $61.1(12.2)$ & $9.6(1.9)$ & $1083(41)$ \\
\hline & Loop 2 (20:05-22:15) & $20.2(3.3)$ & $53.2(17.1)$ & $5.0(1.9)$ & $11635(4155)$ & $1654(436)$ & $2.89(0.68)$ & $72.4(10.1)$ & $10.2(4.3)$ & $1003(112)$ \\
\hline \multirow[t]{2}{*}{ Flight 11} & Loop $1(18: 50-21: 05)$ & $17.2(1.9)$ & $65.6(10.2)$ & $3.4(1.5)$ & $10328(3665)$ & $1580(1987)$ & $2.11(0.33)$ & $46.8(12.8)$ & $6.4(1.6)$ & $1087(32)$ \\
\hline & Loop 2 (21:05-22:50) & $18.4(2.5)$ & $63.2(11.2)$ & $5.3(2.0)$ & $13331(4383)$ & $1521(401)$ & $2.23(0.34)$ & $53.3(11.6)$ & $8.1(3.3)$ & $999(114)$ \\
\hline \multirow[t]{2}{*}{ Flight 13} & Loop $1(18: 10-20: 25)$ & $14.4(2.0)$ & $65.0(22.1)$ & $5.0(3.2)$ & $6815(2501)$ & $1460(654)$ & $1.41(0.53)$ & $56.4(10.5)$ & $4.7(1.0)$ & $829(372)$ \\
\hline & Loop $2(20: 25-22: 10)$ & $17.7(1.8)$ & $60.0(8.8)$ & $4.8(2.1)$ & $10671(4535)$ & $1644(556)$ & $2.27(0.43)$ & $62.0(11.3)$ & $6.4(3.2)$ & $1004(98)$ \\
\hline
\end{tabular}

${ }^{\mathrm{a}}$ Refer to Figures 9 and 10 . Numbers in parentheses represent standard deviations.

flights. There was no significant difference in wind patterns between these two days. Fine particle concentrations were on average similar, but PCASP particle number concentrations were almost twice as large during Flight 8, indicative of more abundant larger particles.

[26] During Flight 5, three identical loops were carried out as shown in Figures 9a-9c: first loop (19:00-20:30, UTC), second loop (20:30-21:50), and third loop (21:50-23:00). When the sea breeze started to develop around 18:00 UTC, wind speeds gradually increased up to $>10 \mathrm{~m} \mathrm{~s}^{-1}$ and changed direction to westerly/southwesterly, resulting in the usual transport from west to east. In the southwestern portion of the Basin, WSOC concentrations were highest during the first loop, presumably owing to the influence of residual aged aerosol from the previous day and anthropogenic emissions near Long Beach. In the first loop, the highest WSOC and PCASP particle number concentrations were observed along the north-south axis between Pasadena and downtown Los Angeles. As a result of the westerly/ southwesterly flow later during the day, the highest WSOC levels occurred at the base of the San Gabriel Mountains at the northern edge of the Basin. The southern half of the Basin loops extending from Fullerton/Anaheim to San Bernardino were characterized by significantly lower WSOC levels during all three loops, most likely a result of the Basin topography (i.e., Puente and Chino Hills). The data from Flight 5 indicate that the significant factors governing WSOC levels were likely residual aerosol in the Basin from the previous day, pollution near the western edge of the Basin, and the prevailing west-to-east winds with potential production during the transport. These data do not allow one to discern a clear connection between WSOC measurements and the influence of boundary layer deepening and potential entrainment of aerosol aloft.

[27] Flight 8 was conducted almost identically to Flight 5, as shown in Figures 9d-9f. In contrast to Flight 5, the aerosol number concentrations and WSOC increased with each successive loop during Flight 8 (similar to ambient temperature and $\mathrm{O}_{3}$ ). The spatial WSOC distribution during the first loop was similar to that of Flight 5 , both of which were likely influenced by residual pollutants from the previous day and sources near the western side of the Basin. WSOC increased significantly in concentration over the western side of the Basin during the second and third loops. Unlike Flight 5, the entire north-south axis between Pasadena and downtown Los Angeles exhibited high WSOC levels later in the day owing likely to a combination of secondary WSOC production and lower wind speeds. The third loop of Flight 8 was characterized by systematically higher WSOC levels across the entire Basin. WSOC levels were especially high between Ontario and Riverside owing to a fire that began immediately prior to the third loop.

[28] The data from both flights indicate that, with higher incident solar radiation and relatively low wind speeds, it is likely that secondary production mechanisms contribute to sustained levels of WSOC throughout the daytime periods (especially in Flight 8) even though the mixing layer progressively deepened. While entrainment of polluted air aloft may have contributed to WSOC levels during these flights, this process was not a dominant influence on WSOC in the mixing layer as there were large spatial differences in WSOC across the Basin that are largely controlled by transport and topography.

\subsection{Basin North-South Transects}

[29] To examine the spatial gradients of WSOC within the regions outlined by the loops in Figure 9, a series of northsouth zig zag patterns were flown within the Los Angeles Basin. The paths during Flights 9, 11, and 13 are shown in Figure 10. The flights were conducted approximately during the same time on different days at a similar altitude $(\sim 300-700 \mathrm{~m})$. Flight 9 was conducted on a Saturday, whereas the other two are from weekdays (Table 1). Meteorological conditions were relatively similar on these three days (Table 3), with the exception of reduced temperature and incident solar radiation values during the early part of Flight 13 due to cloudy conditions. Particle number concentrations were similar during these flights. WSOC concentrations were enhanced during the second loops, coincident with higher $\mathrm{O}_{3}$ concentrations, ambient temperatures, and WSOC: $\mathrm{BC}$ ratios than the first loop within each flight. This is most evident during Flight 13 presumably due to the shift 

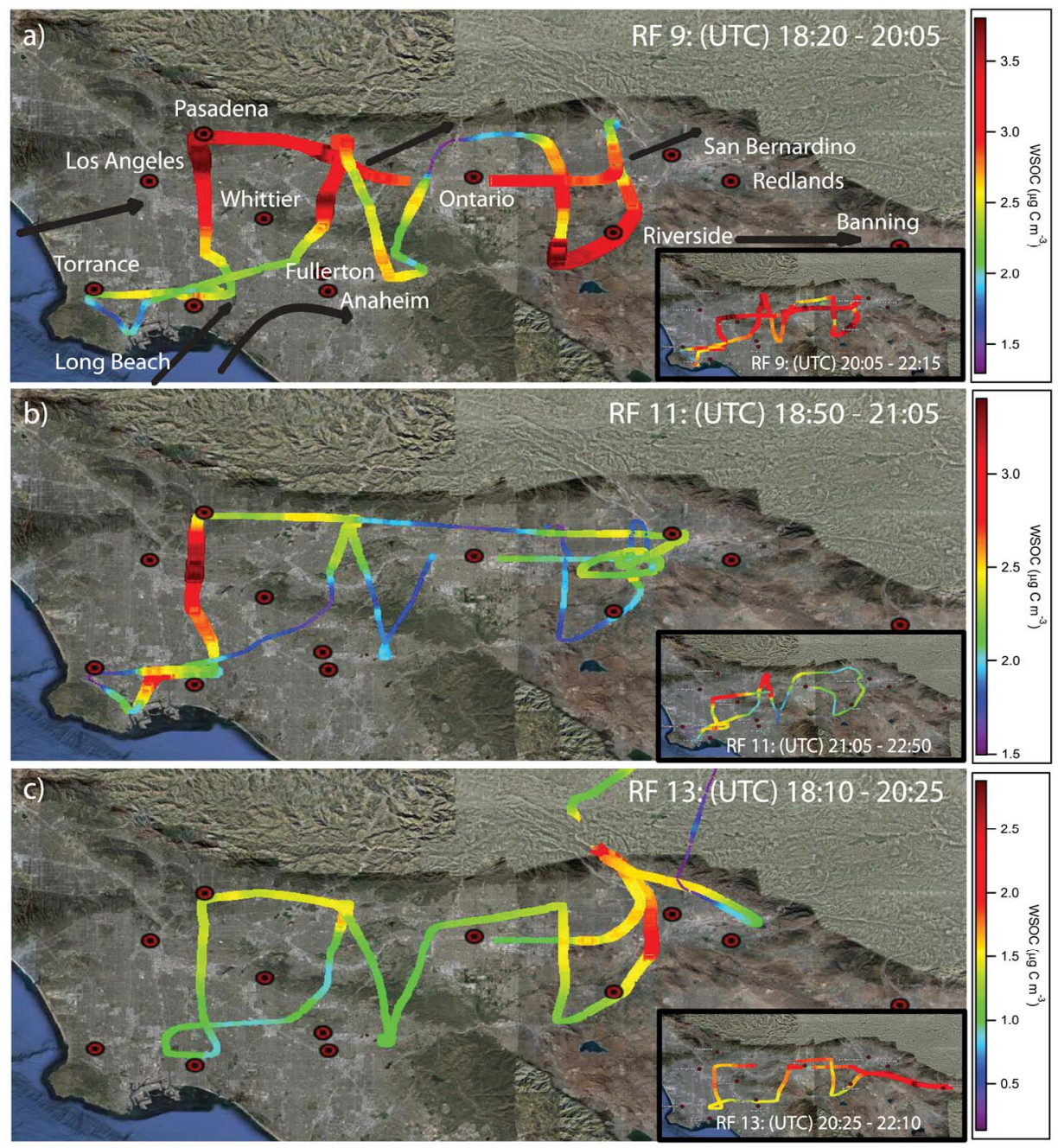

Figure 10. Spatial maps of WSOC during Flights (a) 9 (15 May 2010), (b) 11 (19 May 2010), and (c) 13 (21 May 2010) with black arrows in Figure 10a corresponding to the typical wind directions during the duration of all three flights as determined by wind roses obtained from the Mesowest Database [http:// mesowest.utah.edu/index.html]. Local time $=$ UTC - seven hours.

from cloudy to clear conditions (and increase in incident solar radiation) between the two loops. The absolute increases in WSOC later in the daytime most likely were influenced by secondary production.

[30] These three flights demonstrate the influence of the Basin topography on WSOC levels. The Puente and Chino Hills extending from Whittier to the east create a gradient of low WSOC from south of these hills to higher levels on the north side. Sea breeze winds (westerly/southwesterly) near the coast transport air enriched with WSOC to the north side of these hills, which then gets redistributed across a larger area on the eastern end of the Basin extending from San Bernardino down south to Riverside. In addition to the transport of existing WSOC, there is likely production of these species over inland areas that are characterized by enhanced $\mathrm{O}_{3}$ concentrations (Figure $3 b$ ).

\section{Conceptual Model of WSOC in the Study Region}

[31] Figure 11 shows a conceptual model of the mechanisms describing the sources, transformation, and fate of
WSOC during CalNex. Industrial and marine sources of pollution near the western side of the Basin result in enhanced levels of sulfate and carbonaceous components including WSOC. As aerosol is advected with the sea breeze from the west to the east through the outflows, the overall aerosol composition changes owing to numerous point sources, increasing (decreasing) temperature (RH), amount of aerosol-phase water, and secondary formation processes. For example, VOC emissions lead to SOA formation and primary emissions from episodic fires significantly lead to enhanced levels in organics, especially WSOC. The components comprising WSOC become increasingly oxidized as a function of photochemical age from west-to-east. Near the eastern half of the Basin, $\mathrm{NH}_{3}$ emissions contribute to significant ammonium nitrate formation, leading to more hygroscopic aerosol and increased aerosol-phase water depending on the ambient RH. A number of processes can lead to higher levels of particulate WSOC with increasing aerosolphase water: partitioning of WSOC to the aerosol phase [Hennigan et al., 2008b, 2009], multiphase chemistry [Ervens and Volkamer, 2010; Sorooshian et al., 2010], and 


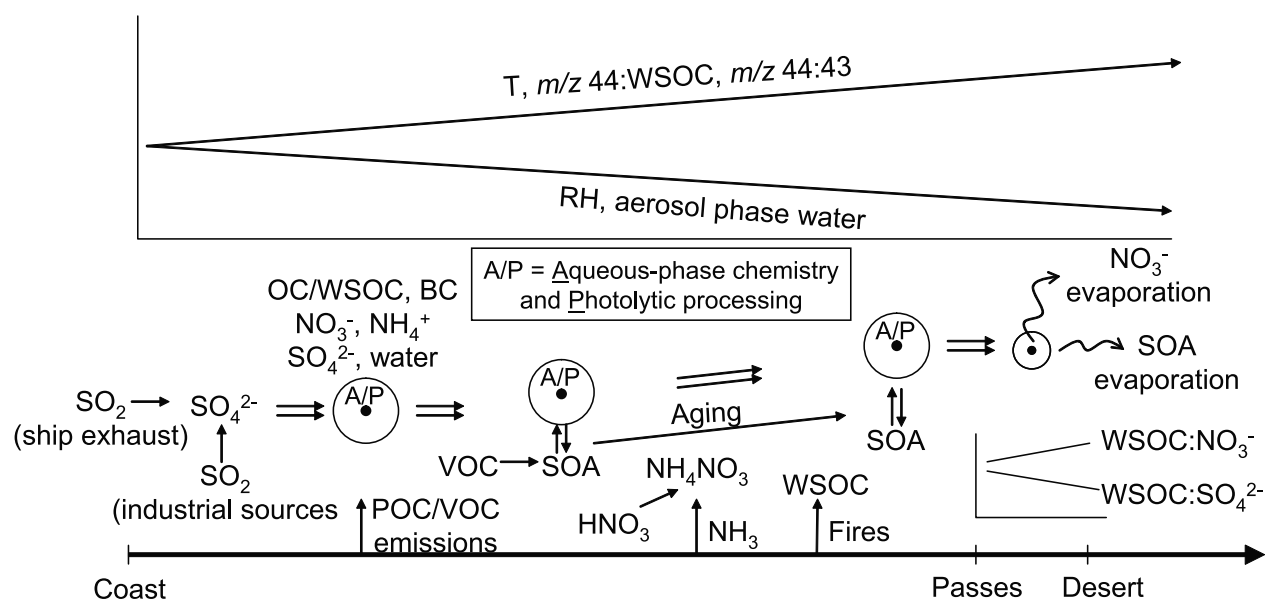

Figure 11. Conceptual model of WSOC in the Los Angeles Basin and desert outflows. The $x$ axis represents longitude and extends from the coast to the desert outflows to the east of the Los Angeles Basin.

photolytic processing [Bateman et al., 2011]. As aerosol is transported through the outflows to desert regions, the enhanced temperatures and reduced $\mathrm{RH}$ result in $\mathrm{NO}_{3}^{-}$ evaporation and consequently, reductions in aerosol-phase water. This may promote re-partitioning of WSOC to the gas phase while suppressing humidity-dependent processes that increase particulate WSOC levels.

\section{Conclusions}

[32] During the May 2010 deployment of the CIRPAS Twin Otter in the CalNex field study, a PILS-TOC instrument was employed to rapidly quantify particulate watersoluble organic carbon (WSOC) during 16 flights covering the Los Angeles Basin, outflow regions, and the San Joaquin Valley. The WSOC measurements were focused on building a spatial map of concentrations across this region in the lateral and vertical directions, on constraining the contribution of these species to the overall aerosol mass budget, and on examining the nature and evolution of this important class of organics due to the prevailing meteorology and daytime air transport patterns.

[33] The highest absolute WSOC concentrations were observed in the Basin (up to $5.3 \mu \mathrm{g} \mathrm{C} \mathrm{m}^{-3}$ ) and the lowest WSOC levels were in the San Joaquin Valley and in Basin outflow regions owing to plume dilution. The highest WSOC levels during individual flights and for the entire campaign occurred in biomass burning plumes from smallscale fires on the eastern side of the Basin. WSOC contributes approximately $6-11 \%$ by mass to $\mathrm{PM}_{2.5}$ within the Basin. WSOC was highest relative to both $\mathrm{PM}_{2.5}$ near the western Basin sites of Torrance and Long Beach, likely owing to these sites being upwind of major pollution sources and influenced by aged marine aerosol and residual pollutants from the previous day. WSOC levels were typically higher above $500 \mathrm{~m}$ in the study region, and layers of enhanced WSOC were identified aloft up to an altitude of $3.2 \mathrm{~km}$. The ratio of WSOC to PCASP particle volume concentration and organic non-refractory mass ranged between $0.11-0.19$ and $0.26-0.63$, respectively, between the surface and $3.2 \mathrm{~km}$.
[34] Simultaneous ground-based measurements of WSOC during aircraft overpasses in Riverside and Pasadena indicate that higher levels occur more frequently aloft within the mixing layer. This was most evident when the ratio of $\mathrm{RH}$ measured on the aircraft versus the surface was also higher, suggestive of an important role for processes that increase particulate WSOC levels as a function of increasing aerosolphase water such as more efficient partitioning to the aerosol phase. Furthermore, WSOC was highly correlated with RH within the Banning Pass area where pollution is funneled out of the Basin to the east. Since aerosol hygroscopicity and ambient RH generally decreased from the Basin to the eastern desert outflows, there was a reduction in aerosolphase water that likely influenced WSOC levels; WSOC levels dropped more relative to both $\mathrm{BC}$ and $\mathrm{SO}_{4}^{2-}$, both of which are non-volatile, downwind of the outflows indicative of partitioning of WSOC to the gas phase and suppression of multiphase processes (i.e., partitioning of WSOC to the aerosol phase, multiphase chemistry, photolytic processing) to produce these species. However, WSOC increased relative to $\mathrm{NO}_{3}^{-}$, suggesting that although both have a semi-volatile character, $\mathrm{NO}_{3}^{-}$was more volatile. Farther downwind in the deserts (e.g., near Salton Sea), WSOC begins to increase relative to $\mathrm{BC}$ indicative of secondary production, especially as $\mathrm{O}_{3}$ levels were enhanced in these areas.

[35] The contribution of acid-like oxygenated organics $(\mathrm{m} / \mathrm{z} 44)$ to WSOC increases from west to east as a result of photochemical aging. Comparisons of nearly identical flight paths on different days show that with higher incident solar radiation and relatively low wind speeds, secondary production mechanisms more clearly contribute to sustained levels of WSOC throughout the daytime periods even though the mixing layer progressively deepens. Entrainment of air aloft may have contributed to WSOC levels within the mixing layer; however, this process was not the key regulator of WSOC in the mixing layer as there were large spatial differences in WSOC across the Basin that are largely controlled by sea breeze transport, topography, secondary production during transport, and presence of fires.

[36] This work adds to the inventory of WSOC data in major mega-cities such as Beijing [Feng et al., 2006], New 
Delhi [Miyazaki et al., 2009], and Mexico City [Hennigan et al., 2008a] showing that WSOC contributes significantly to urban aerosol mass concentrations. The aircraft measurements in CalNex highlight the importance of considering the vertical structure of WSOC in the atmosphere. Surface measurements of WSOC are shown to not be entirely representative of the radiative impact of this class of species. This work also emphasizes the importance of considering spatial gradients in aerosol-phase water. For example, the Los Angeles Basin and outflow regions exhibit large variations in RH and have a variety of sources including shipping and agricultural emissions that can create gradients in aerosol hygroscopicity. The resulting spatial variations in aerosolphase water influence WSOC levels via production processes with efficiencies dependent on this amount of water. Episodic fires and potential volatilization of WSOC point to the use of caution in using ratios of WSOC to other species (e.g., CO and $\mathrm{BC}$ ) in quantifying the magnitude of SOA production.

[37] Acknowledgments. This work was supported by NOAA grant NA 09 OAR 4310128. Surface WSOC measurements were supported by the NSF under grants ATM-0931492 and ATM-0802237.

\section{References}

Aiken, A. C., et al. (2008), O/C and OM/OC ratios of primary, secondary, and ambient organic aerosols with high-resolution time-of-flight aerosol mass spectrometry, Environ. Sci. Technol., 42(12), 4478-4485, doi:10.1021/es703009q.

Bateman, A. P., S. A. Nizkorodov, J. Laskin, and A. Laskin (2011), Photolytic processing of secondary organic aerosols dissolved in cloud droplets, Phys. Chem. Chem. Phys., 13, 12,199-12,212, doi:10.1039/ c1cp20526a.

Blumenthal, D. L., W. H. White, and T. B. Smith (1978), Anatomy of a Los Angeles smog episode: Pollutant transport in daytime sea breeze regime, Atmos. Environ., 12(4), 893-907, doi:10.1016/0004-6981(78)90028-8.

Chow, J. C., J. G. Watson, D. H. Lowenthal, P. A. Solomon, K. L. Magliano, S. D. Ziman, and L. W. Richards (1992), $\mathrm{PM}_{10}$ source apportionment in California San Joaquin Valley, Atmos. Environ., 26(18), 3335-3354.

Chow, J. C., J. G. Watson, D. H. Lowenthal, P. A. Solomon, K. L. Magliano, S. D. Ziman, and L. W. Richards (1993), $\mathrm{PM}_{10}$ and $\mathrm{PM}_{2.5}$ compositions in California San Joaquin Valley, Aerosol Sci. Technol., 18(2), 105-128, doi:10.1080/02786829308959588.

Chow, J. C., J. G. Watson, E. M. Fujita, Z. Q. Lu, D. R. Lawson, and L. L. Ashbaugh (1994), Temporal and spatial variations of $\mathrm{PM}_{2.5}$ and $\mathrm{PM}_{10}$ aerosol in the Southern California air quality study, Atmos. Environ., 28(12), 2061-2080, doi:10.1016/1352-2310(94)90474-X.

Chow, J. C., J. G. Watson, Z. Q. Lu, D. H. Lowenthal, C. A. Frazier, P. A. Solomon, R. H. Thuillier, and K. Magliano (1996), Descriptive analysis of $\mathrm{PM}_{2.5}$ and $\mathrm{PM}_{10}$ at regionally representative locations during SJVAQS/AUSPEX, Atmos. Environ., 30(12), 2079-2112, doi:10.1016/ 1352-2310(95)00402-5.

Chow, J. C., L. W. A. Chen, J. G. Watson, D. H. Lowenthal, K. A. Magliano, K. Turkiewicz, and D. E. Lehrman (2006), $\mathrm{PM}_{2.5}$ chemical composition and spatiotemporal variability during the California Regional $\mathrm{PM}_{10} /$ $\mathrm{PM}_{2.5}$ Air Quality Study (CRPAQS), J. Geophys. Res., 111, D10S04, doi:10.1029/2005JD006457.

Collins, D. R., H. H. Jonsson, H. Liao, R. C. Flagan, J. H. Seinfeld, K. J. Noone, and S. V. Hering (2000), Airborne analysis of the Los Angeles aerosol, Atmos. Environ., 34(24), 4155-4173, doi:10.1016/S1352-2310(00)00225-9.

Decesari, S., et al. (2006), Characterization of the organic composition of aerosols from Rondonia, Brazil, during the LBA-SMOCC 2002 experiment and its representation through model compounds, Atmos. Chem. Phys., 6, 375-402, doi:10.5194/acp-6-375-2006.

Docherty, K. S., et al. (2008), Apportionment of primary and secondary organic aerosols in southern California during the 2005 study of organic aerosols in Riverside (SOAR-1), Environ. Sci. Technol., 42(20), 7655-7662, doi:10.1021/es8008166.
Drewnick, F., et al. (2005), A new time-of-flight aerosol mass spectrometer (TOF-AMS) - Instrument description and first field deployment, Aerosol Sci. Technol., 39(7), 637-658, doi:10.1080/02786820500182040.

Eldering, A., and G. R. Cass (1996), Source-oriented model for air pollutant effects on visibility, J. Geophys. Res., 101(D14), 19,343-19,369, doi:10.1029/95JD02928.

Ervens, B., and R. Volkamer (2010), Glyoxal processing by aerosol multiphase chemistry: Towards a kinetic modeling framework of secondary organic aerosol formation in aqueous particles, Atmos. Chem. Phys., 10(17), 8219-8244, doi:10.5194/acp-10-8219-2010.

Feng, J. L., M. Hu, C. K. Chan, P. S. Lau, L. Y. He, and X. Y. Tang (2006), A comparative study of the organic matter in $\mathrm{PM}_{2.5}$ from three Chinese megacities in three different climatic zones, Atmos. Environ., 40, 3983-3994, doi:10.1016/j.atmosenv.2006.02.017.

Graham, B., O. L. Mayol-Bracero, P. Guyon, G. C. Roberts, S. Decesari, M. C. Facchini, P. Artaxo, W. Maenhaut, P. Koll, and M. O. Andreae (2002), Water-soluble organic compounds in biomass burning aerosols over Amazonia: 1. Characterization by NMR and GC-MS, J. Geophys. Res., 107(D20), 8047, doi:10.1029/2001JD000336.

Grosjean, D., and S. K. Friedlander (1975), Gas-particle distribution factors for organic and other pollutants in Los Angeles atmosphere, J. Air Pollut. Control Assoc., 25(10), 1038-1044.

Hennigan, C. J., et al. (2008a), On the volatility and production mechanisms of newly formed nitrate and water soluble organic aerosol in Mexico City, Atmos. Chem. Phys., 8(14), 3761-3768, doi:10.5194/acp-8-3761-2008.

Hennigan, C. J., M. H. Bergin, J. E. Dibb, and R. J. Weber (2008b), Enhanced secondary organic aerosol formation due to water uptake by fine particles, Geophys. Res. Lett., 35, L18801, doi:10.1029/2008GL035046.

Hennigan, C. J., M. H. Bergin, A. G. Russell, A. Nenes, and R. J. Weber (2009), Gas/particle partitioning of water-soluble organic aerosol in Atlanta, Atmos. Chem. Phys., 9(11), 3613-3628, doi:10.5194/acp-93613-2009.

Hersey, S. P., J. S. Craven, K. A. Schilling, A. R. Metcalf, A. Sorooshian, M. N. Chan, R. C. Flagan, and J. H. Seinfeld (2011), The Pasadena aerosol characterization observatory (PACO): Chemical and physical analysis of the western Los Angeles Basin aerosol, Atmos. Chem. Phys., 11, 7417-7443, doi:10.5194/acp-11-7417-2011.

Hidy, G. M., et al. (1974), Characterization of aerosols in California (ACHEX): Final report, NTIS PB 247, 947 pp., Calif. Air Resour. Board, Sacramento, Calif.

Hildemann, L. M., D. B. Klinedinst, G. A. Klouda, L. A. Currie, and G. R. Cass (1994a), Sources of urban contemporary carbon aerosol, Environ. Sci. Technol., 28(9), 1565-1576, doi:10.1021/es00058a006.

Hildemann, L. M., M. A. Mazurek, G. R. Cass, and B. R. T. Simoneit (1994b), Seasonal trends in Los Angeles ambient organic aerosol observed by high-resolution gas chromatography, Aerosol Sci. Technol., 20(4), 303-317, doi:10.1080/02786829408959687.

Hildemann, L. M., W. F. Rogge, G. R. Cass, M. A. Mazurek, and B. R. T. Simoneit (1996), Contribution of primary aerosol emissions from vegetation-derived sources to fine particle concentrations in Los Angeles, J. Geophys. Res., 101(D14), 19,541-19,549, doi:10.1029/95JD02136.

Hughes, L. S., J. O. Allen, P. Bhave, M. J. Kleeman, G. R. Cass, D. Y. Liu, D. F. Fergenson, B. D. Morrical, and K. A. Prather (2000), Evolution of atmospheric particles along trajectories crossing the Los Angeles Basin, Environ. Sci. Technol., 34(15), 3058-3068, doi:10.1021/es9908671.

Husar, R. B., W. H. White, and D. L. Blumenthal (1976), Direct evidence of heterogeneous aerosol formation in Los Angeles smog, Environ. Sci. Technol., 10(5), 490-491, doi:10.1021/es60116a008.

Husar, R. B., D. E. Patterson, D. L. Blumenthal, W. H. White, and T. B. Smith (1977), 3-dimensional distribution of air-pollutants in Los Angeles Basin, J. Appl. Meteorol., 16(10), 1089-1096, doi:10.1175/1520-045016.10.1089.

Jaffrezo, J. L., G. Aymoz, C. Delaval, and J. Cozic (2005), Seasonal variations of the water soluble organic carbon mass fraction of aerosol in two valleys of the French Alps, Atmos. Chem. Phys., 5, 2809-2821, doi:10.5194/acp-5-2809-2005.

Kanakidou, M., et al. (2005), Organic aerosol and global climate modelling: A review, Atmos. Chem. Phys., 5, 1053-1123, doi:10.5194/acp-51053-2005.

Kawamura, K., and I. R. Kaplan (1987), Motor exhaust emissions as a primary source for dicarboxylic acids in Los Angeles ambient air, Environ. Sci. Technol., 21(1), 105-110, doi:10.1021/es00155a014.

Kleeman, M. J., L. S. Hughes, J. O. Allen, and G. R. Cass (1999), Source contributions to the size and composition distribution of atmospheric particles: Southern California in September 1996, Environ. Sci. Technol., 33(23), 4331-4341, doi:10.1021/es990632p.

Kondo, Y., Y. Miyazaki, N. Takegawa, T. Miyakawa, R. J. Weber, J. L. Jimenez, Q. Zhang, and D. R. Worsnop (2007), Oxygenated and 
water-soluble organic aerosols in Tokyo, J. Geophys. Res., 112, D01203, doi:10.1029/2006JD007056.

Lu, R., and R. P. Turco (1995), Air pollutant transport in a coastal environment-II. Three-dimensional simulations over Los Angeles Basin, Atmos. Environ., 29(13), 1499-1518, doi:10.1016/1352-2310(95)00015-Q.

Magliano, K. L., V. M. Hughes, L. R. Chinkin, D. L. Coe, T. L. Haste, N. Kumar, and F. W. Lurmann (1999), Spatial and temporal variations in $\mathrm{PM}_{10}$ and $\mathrm{PM}_{2.5}$ source contributions and comparison to emissions during the 1995 integrated monitoring study, Atmos. Environ., 33(29), 4757-4773, doi:10.1016/S1352-2310(99)00265-4.

Mayol-Bracero, O. L., P. Guyon, B. Graham, G. Roberts, M. O. Andreae, S. Decesari, M. C. Facchini, S. Fuzzi, and P. Artaxo (2002), Watersoluble organic compounds in biomass burning aerosols over Amazonia: 2. Apportionment of the chemical composition and importance of the polyacidic fraction, J. Geophys. Res., 107(D20), 8091, doi:10.1029/ 2001JD000522.

McElroy, J. L., and T. B. Smith (1986), Vertical pollutant distributions and boundary layer structure observed by airborne lidar near the complex southern California coastline, Atmos. Environ., 20(8), 1555-1566, doi:10.1016/0004-6981(86)90244-1.

McLafferty, F. W., and F. Turecek (1993), Interpretation of Mass Spectra, 4th ed., Univ. Sci., Mill Valley, Calif.

Miyazaki, Y., S. G. Aggarwal, K. Singh, P. K. Gupta, and K. Kawamura (2009), Dicarboxylic acids and water-soluble organic carbon in aerosols in New Delhi, India, in winter: Characteristics and formation processes, J. Geophys. Res., 114, D19206, doi:10.1029/2009JD011790.

Murphy, S. M., et al. (2009), Comprehensive simultaneous shipboard and airborne characterization of exhaust from a modern container ship at sea, Environ. Sci. Technol., 43(13), 4626-4640, doi:10.1021/es802413j.

Neuman, J. A., et al. (2003), Variability in ammonium nitrate formation and nitric acid depletion with altitude and location over California, J. Geophys. Res., 108(D17), 4557, doi:10.1029/2003JD003616.

$\mathrm{Ng}$, N. L., et al. (2010), Organic aerosol components observed in Northern Hemispheric datasets from aerosol mass spectrometry, Atmos. Chem. Phys., 10, 4625-4641, doi:10.5194/acp-10-4625-2010.

Pandis, S. N., J. H. Seinfeld, and C. Pilinis (1992a), Heterogeneous sulfate production in an urban fog, Atmos. Environ., 26(14), 2509-2522.

Pandis, S. N., R. A. Harley, G. R. Cass, and J. H. Seinfeld (1992b), Secondary organic aerosol formation and transport, Atmos. Environ., 26(13), 2269-2282.

Peltier, R. E., R. J. Weber, and A. P. Sullivan (2007a), Investigating a liquidbased method for online organic carbon detection in atmospheric particles, Aerosol Sci. Technol., 41(12), 1117-1127, doi:10.1080/02786820701777465.

Peltier, R. E., A. P. Sullivan, R. J. Weber, C. A. Brock, A. G. Wollny, J. S. Holloway, J. A. de Gouw, and C. Warneke (2007b), Fine aerosol bulk composition measured on WP-3D research aircraft in vicinity of the Northeastern United States-Results from NEAQS, Atmos. Chem. Phys., 7, 3231-3247, doi:10.5194/acp-7-3231-2007.

Ruellan, S., H. Cachier, A. Gaudichet, P. Masclet, and J. P. Lacaux (1999), Airborne aerosols over central Africa during the experiment for regional sources and sinks of oxidants (EXPRESSO), J. Geophys. Res., 104(D23), 30,673-30,690, doi:10.1029/1999JD900804.

Russell, A. G., and G. R. Cass (1984), Acquisition of regional air quality model validation data for nitrate, sulfate, ammonium ion and their precursors, Atmos. Environ., 18(9), 1815-1827, doi:10.1016/00046981(84)90357-3.

Russell, A. G., and G. R. Cass (1986), Verification of a mathematical model for aerosol nitrate and nitric acid formation and its use for control measure evaluation, Atmos. Environ., 20(10), 2011-2025, doi:10.1016/ 0004-6981(86)90342-2.

Russell, A. G., G. J. McRae, and G. R. Cass (1983), Mathematical modeling of the formation and transport of ammonium-nitrate aerosol, Atmos. Environ., 17(5), 949-964, doi:10.1016/0004-6981(83)90247-0.

Sardar, S. B., P. M. Fine, and C. Sioutas (2005), Seasonal and spatial variability of the size-resolved chemical composition of particulate matter $\left(\mathrm{PM}_{10}\right)$ in the Los Angeles Basin, J. Geophys. Res., 110, D07S08, doi:10.1029/2004JD004627.
Schauer, J. J., and G. R. Cass (2000), Source apportionment of wintertime gas-phase and particle-phase air pollutants using organic compounds as tracers, Environ. Sci. Technol., 34(9), 1821-1832, doi:10.1021/ es981312t.

Sorooshian, A., F. J. Brechtel, Y. L. Ma, R. J. Weber, A. Corless, R. C. Flagan, and J. H. Seinfeld (2006), Modeling and characterization of a particle-into-liquid sampler (PILS), Aerosol Sci. Technol., 40(6), 396-409, doi:10.1080/02786820600632282.

Sorooshian, A., S. N. Murphy, S. Hersey, H. Gates, L. T. Padro, A. Nenes, F. J. Brechtel, H. Jonsson, R. C. Flagan, and J. H. Seinfeld (2008a), Comprehensive airborne characterization of aerosol from a major bovine source, Atmos. Chem. Phys., 8(17), 5489-5520, doi:10.5194/acp-85489-2008.

Sorooshian, A., S. Hersey, F. J. Brechtel, A. Corless, R. C. Flagan, and J. H. Seinfeld (2008b), Rapid, size-resolved aerosol hygroscopic growth measurements: Differential aerosol sizing and hygroscopicity spectrometer probe (DASH-SP), Aerosol Sci. Technol., 42(6), 445-464, doi:10.1080/02786820802178506.

Sorooshian, A., S. M. Murphy, S. Hersey, R. Bahreini, H. Jonsson, R. C. Flagan, and J. H. Seinfeld (2010), Constraining the contribution of organic acids and AMS m/z 44 to the organic aerosol budget: On the importance of meteorology, aerosol hygroscopicity, and region, Geophys. Res. Lett., 37, L21807, doi:10.1029/2010GL044951.

Sullivan, A. P., R. E. Peltier, C. A. Brock, J. A. de Gouw, J. S. Holloway, C. Warneke, A. G. Wollny, and R. J. Weber (2006), Airborne measurements of carbonaceous aerosol soluble in water over northeastern United States: Method development and an investigation into water-soluble organic carbon sources, J. Geophys. Res., 111, D23S46, doi:10.1029/ 2006JD007072.

Takegawa, N., T. Miyakawa, K. Kawamura, and Y. Kondo (2007), Contribution of selected dicarboxylic and $\omega$-oxocarboxylic acids in ambient aerosol to the $\mathrm{m} / \mathrm{z} 44$ signal of an Aerodyne aerosol mass spectrometer, Aerosol Sci. Technol., 41, 418-437, doi:10.1080/02786820701203215.

Vutukuru, S., R. J. Griffin, and D. Dabdub (2006), Simulation and analysis of secondary organic aerosol dynamics in the South Coast Air Basin of California, J. Geophys. Res., 111, D10S12, doi:10.1029/2005JD006139.

Wall, S. M., W. John, and J. L. Ondo (1988), Measurement of aerosol size distributions for nitrate and major ionic species, Atmos. Environ., 22(8), 1649-1656, doi:10.1016/0004-6981(88)90392-7.

Wonaschütz, A., S. Hersey, A. Sorooshian, J. Craven, A. R. Metcalf, R. C. Flagan, and J. H. Seinfeld (2011), Impact of a large wildfire on watersoluble organic aerosol in a major urban setting: The 2009 station fire in Los Angeles County, Atmos. Chem. Phys., 11, 8257-8270, doi:10.5194/ acp-11-8257-2011.

Zhang, Q., M. R. Alfarra, D. R. Worsnop, J. D. Allan, H. Coe, M. R. Canagaratna, and J. L. Jimenez (2005), Deconvolution and quantification of hydrocarbon-like and oxygenated organic aerosols based on aerosol mass spectrometry, Environ. Sci. Technol., 39(13), 4938-4952, doi:10.1021/ es0485681.

Zhang, X. Q., P. H. McMurry, S. V. Hering, and G. S. Casuccio (1993), Mixing characteristics and water-content of submicron aerosols measured in Los Angeles and at the Grand Canyon, Atmos. Environ., 27(10), 1593-1607.

J. S. Craven, R. C. Flagan, S. P. Hersey, A. R. Metcalf, and J. H. Seinfeld, Department of Environmental Science and Engineering, California Institute of Technology, 1200 E. California Blvd., Pasadena, CA 91125, USA.

H. T. Duong and A. Sorooshian, Department of Chemical and Environmental Engineering, University of Arizona, PO Box 210011, Tucson, AZ 85721, USA. (armin@email.arizona.edu)

H. Jonsson, Center for Interdisciplinary Remotely-Piloted Aircraft Studies, Naval Postgraduate School, Monterey, CA 93943, USA.

R. J. Weber and X. Zhang, School of Earth and Atmospheric Sciences, Georgia Institute of Technology, Atlanta, GA 30332, USA. 